Discussion Paper No. 505

\title{
BANK LENDING IN JAPAN: \\ ITS DETERMINANTS AND \\ MACROECONOMIC IMPLICATIONS
}

\author{
Kazuo Ogawa \\ and \\ Shin-ichi Kitasaka
}

April 2000

The Institute of Social and Economic Research

Osaka University

6-1 Mihogaoka, Ibaraki, Osaka 567-0047, Japan 


\title{
Bank Lending in Japan: \\ Its Determinants and Macroeconomic Implications *
}

\author{
Kazuo Ogawa \\ Institute of Social and Economic Research, Osaka University \\ 6-1 Mihogaoka, Ibaraki,Osaka 567 JAPAN
}

Shin-ichi Kitasaka

Graduate School of International Cooperation Studies, Kobe University

2-1 Rokkodai-cho, Nadaku, Kobe 657 JAPAN

* This is an extended version of the paper with the same title to be published in Hoshi, T. and H. Patrick, Crisis and Change in the Japanese Financial System, Kluwer Academic Publishers, 2000. This paper was presented at the conference, " The Japanese Financial System: Restructuring for the Future," at Columbia University on October 1 and 2, 1998. Early version of the paper was presented at the Finance Forum, Kobe University, Nagoya City University and Osaka University. We thank Anil Kashyap, and two editors of this volume, Takeo Hoshi and Hugh Patrick for numerous suggestion and comments in improving the quality of the paper. We are also grateful to Charles Calomiris, Kenya Fujiwara, Atsuo Fukuda, Yuzo Honda, Charles Yuji Horioka, Kiyoshi Kuga, Katsumi Matsuura, Eiji Nezu, Yoshiyasu Ono, Fumio Ohtake, Makoto Saito, Masaya Sakuragawa, Toshiaki Tachibanaki, Yasuhiko Tanigawa, Hideki Toya, Yoshiro Tsutsui, Yasuharu Ukai and the conference participants for helpful comments and suggestions. This research was partially supported by grants-in-aid of Asset Management Service Industry in Osaka School of International Public Policy of Osaka University. Any remaining errors are the sole responsibility of the authors. 


\section{Summary}

We examine the role of bank loans in the Japanese economy by analyzing the lending behavior of banking firms and the investment behavior of non-financial firms. As for the banks' behavior, we construct a dynamic model of lending and test a variety of behavioral hypotheses on the bank's loan supply based on the panel data set over 1976 to 1995. Our main finding is that the lending behavior is quite different by types of banks and of borrowers. For regional banks the bank loans are sensitive to deposits, indicating that they face imperfections in capital market. For major banks such as city banks, real estate plays a vital role as collateral in loan contracts. We also find that loans to small and/or non-manufacturing firms are more dependent on real estate as collateral and sensitive to the deposit growth. It is inferred that real estate functions as a device to reduce the agency cost stemming from the asymmetric information between borrowers and banks.

We also find that expenditure on fixed investment is much more sensitive to bank loans for small firms than for large firms. Our simulation exercises demonstrate that cut of loan supply is largely responsible for the stagnancy of investment in the downturns after the burst of the bubble and the financial turmoil in 1997. To sum up, lending channel is indeed important in Japan in propagating the shocks in the asset markets to the real economy.

JEL Classification Number: G21

Key Words: Lending channel, Bank loans, Liquidity constraint, Collateral, Euler equation, Generalized method of moments estimator, Investment function, Credit Crunch

Correspondence to : Kazuo Ogawa,

Institute of Social and Economic Research, Osaka University,

6-1 Mihogaoka, Ibaraki, Osaka, 567-0047 JAPAN

Tel: +81- 6- 6879-8570 Fax: +81- 6-6878-2766Ｅ-mail: ogawa@iser.osaka-u.ac.jp 
1.Introduction

The year of 1997 was full of failures of financial institutions for the Japanese economy. In November large financial corporations such as The Hokkaido Takushoku Bank and Yamaichi Securities Co. Ltd., went into bankruptcy. It prompted the risk-avert households to shift deposits from the banks perceived to be in trouble to safe banks. The increase rate of deposits in December from previous year was $6.2 \%$ and $4.7 \%$ for postal savings and city banks, while it was only $1.6 \%$ and $-2.1 \%$ for regional banks and the second regional banks, respectively. Many argue that quick shift of deposits, together with fall of share price, makes banks very cautious in making loans or even worse withdraw loans to maintain the requirement on bank capital. It is further asserted that a contraction of bank credit in turn will choke off the real activity of bank-dependent firms and thus aggravate the current stagnancy of the Japanese economy.

The assertion above presumes that bank credit does play an important role in supporting the real activity in the Japanese economy. It should be noted, however, that this assertion crucially hinges upon the substitutability among the balance sheet items of banking firms as well as borrowers. Suppose that a negative shock hits the deposit of one bank. When the substitutability of reservable deposits and the other items of balance sheet of bank is perfect, then the bank can offset the deposit shock completely and its lending behavior will not be affected at all by the shock. Even if the substitutability is imperfect for the bank, the borrowers can offset the cut of bank loans by raising the funds from another source when the substitutability between bank loans and other ways of financing is perfect for the borrowers. Thus it is only when the degree of substitutability is imperfect for both banks and borrowers that the shocks to the banks' balance sheet are propagated into the real economy by way of bank loans.. This propagation channel is well-known lending channel and bank credit does play a vital role in transmitting a change in monetary policy. ${ }^{1}$

Our goal in this study is to examine the role of bank credit in the Japanese economy. To achieve this goal, we proceed in the following two steps. First of all, we analyze the lending behavior of the Japanese banking firms based on the panel data set of commercial banks in the period of 1976 to 1995 . Then we turn to an analysis of borrowers. Specifically, we focus on the effect of bank loans on fixed investment of non-financial firms, which constitutes a key 
component of business fluctuations.

There are four features in our study. Three features are associated with the analysis of banking firms and the other is associated with that of non-financial firms. First of all, we estimate the Euler equation of bank loans derived from the intertemporal model of banking firms. There are very few studies that examine the lending behavior of Japanese banking firms from the viewpoint of intertemporal maximization principle. ${ }^{2}$

Second, since our data set contains four different types of banks: city banks, long-term credit banks, trust banks and regional banks, the following analysis will be conducted by categorizing our sample banks broadly into two types of banks: regional banks and major banks (city banks, long-term credit banks and trust banks). ${ }^{3}$ There are noticeable differences between the two types of banks in terms of size, position in inter-bank market, composition of liabilities and so forth. It is interesting to see how the lending behavior differs between the two types of banks.

Third, the sample period of our panel data set is from the fiscal year of 1976 to 1995 , which includes numerous interesting events in the financial scenes. To mention a few, financial liberalization and internationalization had been under progress and large firms became less dependent on bank loans and raised the fund directly from capital market. In the midst of the bubble period from the late 1980's to the early 1990's banks increased bank credit tied with real estate enormously. Soaring asset prices were followed by sharp fall of them, which plunged a number of banks into financial troubles, which some argue is mainly responsible for lingering recession of the Japanese. The Basle Accord, which was reached in June 1988, put another constraint on banks engaging in international business in such a manner that the ratio of bank capital to bank assets should be kept above the minimum requirement ratio, $8 \%$. It presumably affects the bank's portfolio balance, especially lending activity.

The virtue of our dynamic modeling of banking firm is its ability to examine the effects of such episodes on the bank's lending behavior empirically. Specifically we focus on three episodes and examine how each of them affected bank's lending behavior. One is the role of real estate as collateral in loan contract in the bubble period. We examine for what type of banks and borrowers real estate is important as collateral. ${ }^{4}$ The second episode we are interested in is the introduction of regulation on bank capital (Basle Accord) that took full effect in 1993. New 
regulation on bank capital can be incorporated formally into our dynamic model and its effect on lending behavior is examined empirically. The third episode we are interested in is the extent to which a shift of deposits from one bank to another, which occurred soon after the collapse of large financial corporations in November in 1997, affects the lending behavior of banks. This is nothing but to investigate into the substitutability of reservable deposits and the other items of balance sheet of banks. As was discussed earlier, imperfection of substitutability is necessary for the shocks to the banks' balance sheet to be propagated into the real economy by way of bank loans.

Fourth, we estimate the investment function of non-financial firms by industry and firm size. Large firms have much more variety of ways of financing than small firms. Therefore it is expected that bank loan is much more important for small firms. Estimation of investment function by firm size enables us to examine this conjecture. Furthermore, based on the estimates of investment function, we simulate the extent to which a change in loan supply affects the investment activities with different firm size to obtain the impact on the aggregate investment.

Now we preview our main findings. First, we find that real estate played a vital role as collateral for loans to small and/or non-manufacturing firms by major banks such as city banks, long-term credit banks and trust banks. Progress of financial liberalization enabled large nonfinancial corporations, especially in manufacturing industries, affiliated with these banks to raise funds directly from capital market, which made the banks lend to small and/or nonmanufacturing firms with which they had not established close ties. The problem of asymmetric information is severe in this situation, and it is the real estate as collateral that has a role to mitigate this problem by decreasing the default risk. Note that real estate had been correctly judged to be the most safe form of collateral for the entire postwar period until 1990 since real estate price had not ever declined significantly and loans were only for a certain proportion (60 $80 \%)$ of the appraised market value.

Second, the loans by regional banks are quite sensitive to deposits and this is especially so for loans to small and/or non-manufacturing firms. Third, as for the introduction of BIS capital adequacy requirements on bank capital, we detect significant effect on lending behavior of major banks. Fourth, expenditure on fixed investment of small firms are much more sensitive to bank loans than that of large firms. Our simulation results indicate that the contraction of loan supply 
in the early 1990's as well as the collapse of large financial institutions in fall of 1997 had tremendous negative effects on fixed investment of small and non-manufacturing firms.

Taken together, our evidence implies that the shocks in the asset markets are propagated into the real activity of bank-dependent firms via bank loan and thus the lending channel is especially important in the Japanese economy.

The paper is organized as follows. The next section will describe the major characteristics of lending behavior of the Japanese banking firms in the late 1970's to the middle of 1990's, while Section 3 describes the major characteristics of investment activities of the Japanese nonfinancial firms in the 1970's to the 1990's. Section 4 develops a dynamic model of banking firm and derives an Euler equation of loans. Section 5 describes the data set employed for estimation and discusses econometric issues in estimating the Euler equation and testing hypotheses on the bank's lending behavior. Section 6 shows the estimation results and interprets them. Section 7 estimates the investment function by firm size with special focus on the role of bank loan and then evaluates the effects of change in loan supply on investment quantitatively by simulation technique. Section 8 concludes this study.

2. Characteristics of Lending Behavior by Japanese Banks in the late 1970's to the 1990's

It is our task in this section to describe the characteristics of bank lending on the basis of our panel data set, which is collected from the Nikkei NEEDS Company Data Base. Our data set consists of 139 banks for the period of 1976 to 1995. The sample banks are categorized into four types of banks: 7 city banks, 3 long-term credit banks, 7 trust banks and 122 regional banks. They are chosen on the criterion that there are no large merges or acquisitions during the sample period. ${ }^{5}$

Let us first look at the growth rate of bank loans for the sample period. Figure 1 shows the growth rate of bank loans separately for the four types of banks. Table 1 gives a summary table of the average of growth rate of bank loans for the whole sample period (1977-1995) as well as three subperiods (1977-1986, 1987-1990, and 1991-1995). The pattern of growth rate is quite similar across the four types of banks. There are spikes in the growth rate for the period of 1982, 1985, and 1990. The growth rate also shares a common increasing trend from 1986 to 1990 so called " bubble period " except for trust banks. The growth rate fell sharply in 1991 with the 
declining trend prevalent for the rest of our sample period. In particular the growth rate plunged into negative in 1993 for long-term credit banks and in 1994 for city banks and trust banks. Contrasted with two-digit growth rate during the bubble period, the average growth rate of bank loans was only $1.07 \%,-0.02 \%, 0.06 \%$ and $3.81 \%$, respectively, for city banks, long-term credit banks, trust banks and regional banks for the period of 1991 to 1995 . Note that a regulation on loans to real estate industry took effect in April in 1990, which might have had a direct effect on bank lending.

Three characteristics of bank lending in the late 1970's to the 1990's deserve pointing out. First of all, bank lending shifted from large firms to small firms, irrespective of the type of banks. ${ }^{6}$ Figure 2 shows the proportion of bank loans to small firms over 1977 to 1995 . Table 2 summarizes the sample mean of the proportion of small firms in loan stock for the whole sample period (1977-1995) and three subperiods( 1977-1986, 1987-1990, and 1991-1995). The largest shift is observed for trust banks. The share of small firms was merely $17.8 \%$ in 1977 and it jumped up to $44.1 \%$ in 1988 . The share of small banks in bank loans also increased by more than 20 percentage points for city banks and long-term credit banks. Even the regional banks, whose proportion of bank loans to small firms is by far larger than any other type of banks, increases the share of small banks in bank loans gradually in the 1970's to the 1980's.

Secondly, we observe an interesting pattern of bank loans secured by real estate. Figure 3 shows the proportion of bank loans secured by real estate and Table 3 gives the sample mean of the proportion of bank loans secured by real estate. For city banks the proportion rose noticeably during the middle of 1980 's to the early 1990's, reversing a declining trend from 1977 (18.5\%) to 1985 (15.1\%). It started to rise in 1986 and reached its peak in 1991 (23.0\%). Although the proportion exhibits a sharp declining trend for long-term credit banks and trust banks from the late 1970 's to the late 1980 's, it leveled off in the 1990's. For regional banks the proportion is rather stable in the range of $36.5 \%$ (1977) to $39.9 \%$ (1993). Casual observation hints that sharp hike of land price in the bubble period might be responsible for a rise in loan shares secured by real estate for city banks or more dependence of loans on real estate for long-term credit banks and trust banks.

The third characteristic, which is related to the second, is a tilt of bank loans toward nonmanufacturing industries especially tertiary industries. Figure 4 shows the proportion of bank 
loans to non-manufacturing industries for the four types of banks. What is common to all types of banks is an increasing trend of bank loans to non-manufacturing industries until 1990. The trend is especially noticeable for long-term banks and trust banks. The share of loans to nonmanufacturing industries is $56.4 \%$ and $62.0 \%$, respectively, for long-term banks and trust banks in 1977 , but it rises to as high as $90.5 \%$ and $93.1 \%$ in 1990 . Table 4 gives the average growth rate of bank loans for major industries. The growth rate of bank loans is highest for financial institutions for the period of 1977-1986 and 1987-1990, followed by personal loans excluding housing loans, real estate, and service industries. The growth rate of bank loans to financial institutions amounts to $30 \%$ and $25 \%$ per annum in the period of 1977-1986 and 1987-1990, respectively. Since financial institutions include non-deposit money corporations engaged in the provision of finance, credit and investment, so called non-banks, and they loaned out what they borrowed from banks to real estate and construction industries in the late 1980's to the early 1990 's, the average growth rate of loans to real estate industry in Table 4 will probably underestimate the actual figures.

By combining the three characteristics stated above, it is conjectured that real estate played a collateral role in loan contracts between banks and new customers in the bubble period. When there exists asymmetry in information between lenders and borrowers, real estate, expected to rise in value or at least not to decline in value by any serious amount or for any sustained period of time, will be quite potent to lessen the default risk. Major banks increased their search for lending to small and/or non-manufacturing firms who were new clients. Similarly regional banks also sought new clients (as some of their established clients switched to some of the major banks) in the process of taking them away from credit associations and credit cooperatives. Thus as both major and regional banks tilt their loans toward new clients, it is likely that asymmetry of information becomes more severe. We will examine this conjecture empirically, based on an intertemporal model of banking firms developed in Section 4.

3. Characteristics of Investment Behavior by Japanese Non-financial Firms in the late 1970's to the 1990's

In this section we describe the characteristics of fixed investment of the Japanese non- 
financial firms in the late 1970's to the 1990's. In particular we place emphasis on the comparison of the investment behavior across industry and firm size since the effect of bank lending on investment is expected to vary, depending on the firm size and the industry.

We use the quarterly data in the Quarterly Report of Financial Statements of Incorporated Business or Hojin Kigyo Tokei Kiho (abbreviated as QRFS) of the Ministry of Finance. The QRFS reports quarterly the major items of balance sheet and profit and loss statement disaggregated by firm size for the manufacturing industries as well as for non-manufacturing industries. The measure of firm size is capital. In original format there are five size classes of firms, but for the purpose of simplifying the analysis we aggregate the size categories into three groups, each of which corresponds to small, medium, and large firm group. Small firm group includes the firms under $¥ 100$ million yen in capital. Medium firm group includes the firms between $¥ 100$ and $¥ 1000$ million yen in capital. Large firm group includes the firms over $¥ 1000$ million yen in capital.

. There is one problem in making use of the time series data in the QRFS. That is discontinuity of the data series. This arises from a complete renewal of the corporations in the sample every April. After renewing the sample in April, they are fixed for one year. It is necessary to adjust the discontinuous data series in a consistent manner. Fortunately the survey contains for the main items in the balance sheet the values of the beginning and end of each period covered for the same sample. This implies that we can compute the time series of flow variables consistently. As for a series of investment, we use the new increment of construction in progress and assets of property, plant, and equipment. The loan data includes that in liquid liabilities as well as in fixed liabilities. Once the flow series become available, perpetual inventory method can be used to construct the series of capital stock and loan outstandings. ${ }^{7}$

The shares of gross fixed investment in 1997 nominal private aggregate fixed investment are $3.5 \%, 3 \%, 13.9 \%, 11 \%, 7.1 \%$, and $24.8 \%$ for small, medium, and large firm groups in manufacturing industries and for small, medium, and large firm groups in non-manufacturing industries, respectively. The rest of fixed investment (36.7\%) comes from financial institutions and small non-incorporated businesses, the latter of which occupies most of the share. Figure 5 depicts the gross fixed investment rate from the second quarter of 1975 to the first quarter of 1998. The investment rate of manufacturing industries is shown in Figure 5-1. We observe three 
peaks in investment rate common to three firm groups. They are centered around 1980, 1984 to 1985, and 1989 to 1991. Each corresponds to boom periods in the Japanese economy. However, the peaks are more pronounced for small firm group and for the long-lived boom called Heisei Keiki starting from the fourth quarter of 1986 . We also observe precipitous fall of investment rates from 1991 to 1994 for all firm groups during severe downturns after the bubble burst (Heisei Fukyo). Figure 5-2 shows the investment rate of non-manufacturing industries. Here the peaks of investment rate are less conspicuous except for small firm group. For small firm group the peak reaches as high as $6.6 \%$ in the fourth quarter of 1989 . Common to all the firm groups is the sharp fall of investment rate from 1991 to 1994.

Table 5 shows the sample average of the gross fixed investment rate over the whole sample period as well as three subperiods. They are the second quarter of 1975 to the fourth quarter of 1986, the first quarter of 1987 to the first quarter of 1991(Heisei Keiki), and the second quarter of 1991 to the first quarter of 1998 (Heisei Fukyo). The average gross fixed investment rate is highest in the second subperiod and lowest in the third subperiod for manufacturing as well as non-manufacturing industries. This indicates that the fixed investment was the driving force of the booms in the late 80 's, although it remained stagnant in the 90 's. Note that the volatility of fixed investment in terms of standard deviation is highest in small firm group for both manufacturing and non-manufacturing industries.

\section{Intertemporal Model of Banking Firms}

We construct an intertemporal model of banking firms and derive an Euler equation to be examined empirically. Our model is general enough to test a variety of hypotheses on the lending behavior of banking firms such as the role of collateral, effect of regulation on bank capital requirement, excess sensitivity of bank loans. The banking firm chooses the optimal level of bank loans, call money borrowing and security holdings given the level of deposit and bank capital so that the value of firm can be maximized. ${ }^{8}{ }^{9}$ The banking firm is subject to two constraints: reserve requirement on deposits and minimum requirement on the ratio of bank capital to bank assets. The balance sheet of the banking firm is shown in Figure $6 .{ }^{10}$

There are two types of cost associated with making loans. One is the agency cost arising from the asymmetry between lenders and borrowers, which depends on how long the bank 
customers have been affiliated with the banks. The longer the bank-customer relationship is, the less severe the asymmetric information is. The agency cost is highest for the loans to new clients. Since larger change in loan stock usually accompanies larger volume of loans to new customers, especially during our sample period, we assume that the agency cost is an increasing function of net change in bank loans. ${ }^{11}$

The other loan-related cost is the expected cost of default. The larger the loan stock is, the larger is the probability that part of the loan goes into default. Hence it is assumed that the default cost is an increasing function of loan stock. However, the default cost may depend on whether the loan is secured and if so on the value of collateral. As was shown in the previous section, land has played a vital role of collateral in Japan. We examine the role of land as collateral formally by including the change in land price as a shift variable in the default cost function.

Lastly, note that the loan-related cost depends on the size of bank. The same change of loan stock will cost less for larger banks. Larger bank has the capacity to diversify loan risks. We measure the size of bank by the sum of deposit and bank capital.

To summarize, the loan-related cost is an increasing function of net flow of bank loans and loan stock and a decreasing function of the sum of deposit and bank capital.

In what follows we assume that the banking firm will hold minimum balance of required reserves since it bears no interest. Maximization of the value of banking firm subject to the two constraints and the balance sheet identity yields the first order condition for bank loans. According to the first order condition, the optimal level of bank loans is determined in such a manner that the marginal cost of loans may be equal to the discounted marginal revenue of loans in the next period including the savings of the cost associated with adjusting the loan in the next period and the expected default cost arising from the change in the current loan stock. Note that the marginal cost will be higher for banks with the capital requirement constraint binding.

For the purpose of estimation, we assume the following type of loan-related cost function: 


$$
\begin{aligned}
C\left(F L_{t}, L_{t-1}, D_{t-1}+C A P_{t-1}\right) & =\left[\alpha_{0}\left(\frac{F L_{t}}{D_{t-1}+C A P_{t-1}}-\mu\right)+\frac{\alpha_{1}}{2}\left(\frac{F L_{t}}{D_{t-1}+C A P_{t-1}}-\mu\right)^{2}\right]\left(D_{t-1}+C A P_{t-1}\right) \\
& +\left[\alpha_{2} \frac{L_{t-1}}{D_{t-1}+C A P_{t-1}}\right]\left(D_{t-1}+C A P_{t-1}\right)
\end{aligned}
$$

where $\quad L_{t-1}:$ loan stock at the end of period t-1

$D_{t-1}:$ deposit stock at the end of period t-1

$F L_{t}$ : net flow of bank loans in period $\mathrm{t}$

$C A P_{t-1}$ : bank capital at the end of period t-1

$\alpha_{1}>0, \alpha_{2}>0$

Substituting the loan-related cost function above into the first order condition and arranging terms under the assumption that the banking firm forms expectations rationally, we obtain the following optimal loan supply equation.

$$
\begin{aligned}
& \frac{F L_{t}}{D_{t-1}+C A P_{t-1}}-\left(1+r_{t+1}\right)^{-1}\left(\frac{F L_{t+1}}{D_{t}+C A P_{t}}\right)=\beta_{0}+\beta_{1}\left(1+r_{t+1}\right)^{-1} \\
& +\beta_{2}\left(1+r_{t+1}\right)^{-1}\left(r_{L, t+1}-r_{C, t+1}\right)-\frac{q}{\alpha_{1}} \lambda_{t}+v_{t+1} \\
& \text { where } \beta_{0}=\mu-\frac{\alpha_{0}}{\alpha_{1}} \\
& \beta_{1}=\frac{\alpha_{0}-\alpha_{2}}{\alpha_{1}}-\mu \\
& \quad \beta_{2}=\frac{1}{\alpha_{1}} \\
& r_{t+1}: \text { one-period required rate of return in period } \mathrm{t} \\
& r_{L, t+1}: \text { interest rate on bank loans in period } \mathrm{t}+1 \\
& r_{C, t+1}: \text { call rate in period } \mathrm{t}+1 \\
& \lambda_{t} \text { : non-negative Lagrangean multiplier associated with the requirement on } \\
& \text { bank capital }
\end{aligned}
$$




$$
\begin{aligned}
& q: \text { minimum required ratio of bank capital to loans } \\
& v_{t+1}: \text { forecast error }
\end{aligned}
$$

Eq.(2) is the basic equation to be estimated in the subsequent sections. The ratio of net lending to the bank size, measured by the sum of deposit and capital, is a function of interest differentials between the loan interest rate and the call rate, required rate of return, non-negative Lagrangean multiplier, and the future lead variables of the ratio of net lending to the bank size.

It should be noted that the forecast error $v_{t+1}$ is uncorrelated with any variables contained in the bank's information set in period $t$ under rational expectation assumptions. This property proves to be very useful in conducting a test of some hypotheses on the banking firm's behavior.

\section{Procedures of Estimation and Hypotheses Testing of the Bank's Lending Behavior}

To begin with, we modify eq.(2) so that we may test several hypotheses on the bank's lending behavior. Then we will discuss econometric issues in estimating the Euler equation, followed by the description of the data set.

\section{A. Formulation of Hypotheses on the Lending Behavior of Banking Firm}

Let us first state the stripped-down version of the loan supply equation where the regulation of bank capital requirement is not binding. It is written as

$$
\begin{aligned}
\frac{F L_{t}}{D_{t-1}+C A P_{t-1}}-\left(1+r_{t+1}\right)^{-1} & \left(\frac{F L_{t+1}}{D_{t}+C A P_{t}}\right)=\beta_{0}+\beta_{1}\left(1+r_{t+1}\right)^{-1} \\
& +\beta_{2}\left(1+r_{t+1}\right)^{-1}\left(r_{L, t+1}-r_{C, t+1}\right)+v_{t+1}
\end{aligned}
$$

As was seen in the previous section, the proportion of loans secured by real estate rose in the bubble period for city banks. For the other types of banks, its declining trend ceased in the same period. These observation hints that land price might affect the loan supply schedule of the banking firms.

Formally this idea can be incorporated into the model by formulating the rate of change in land price as a shift variable of the default cost function. ${ }^{12}$ Specifically, the parameter of $\alpha_{2}$ in the 
loan-related cost function can be expressed as a linear function of the rate of change in land price. In other words,

$$
\begin{gathered}
\alpha_{2}=\alpha_{2}^{\prime}-\alpha_{3}^{\prime} \frac{p_{t-1}^{L}}{p_{t-2}^{L}} \\
\text { where } \alpha_{3}^{\prime}>0 \\
p_{t-1}^{L}: \text { land price in period } \mathrm{t}-1
\end{gathered}
$$

An increase of land price leads to a rise in collateral value and hence reduces the expected cost of default.

It is a well-known procedure to add extra terms such as cash flow or some kind proxy of internal funds in investment function to test the existence of liquidity constraints of non-financial firms. The same procedure is applicable in our case to test whether the banking firm is constrained in the capital markets. Suppose that a negative shock hits the bank's deposits and a large amount of deposits is withdrawn unexpectedly from the bank. When the banking firm is not constrained in the capital market, it can offset the shocks to the bank's deposits completely by borrowing in the call market, or issuing CD's even if the bank does not hold securities to cushion the negative shock. Thus its lending behavior will be unaffected by shocks. On the other hand, when the banking firm is constrained in the capital market and do not hold enough liquid assets, then the lending volume will be sensitive to the shocks and the original shocks on the bank's balance sheet will be transmitted to the real economy unless the borrowers have perfect substitutes for bank loans. This implies that the lending channel is indeed working in transmitting the policy shocks into the real economy. Thus whether the banking firm is constrained in the capital market or not has important implications on the transmission mechanism of monetary policy.

In the framework of intertemporal model developed above, it is easy to test rigorously whether the banking firm is constrained in the capital market. Since the forecast error in eq.(2) is uncorrelated with any elements in the bank's information set in period t, the lending behavior by unconstrained banks will not be affected at all by them even if they are added to the explanatory variables. One natural candidate will be the growth rate of deposits. ${ }^{13}$ If the growth rate of deposits does matter for the bank's lending, it is an indication that the bank is constrained in the 
capital market and does not have enough liquid assets. The testing procedure is simply to add the growth rate of deposits to the explanatory variables and test whether its coefficient is significant or not.

When we incorporate the two hypotheses on lending behavior: collateral role of land in loan contracts and imperfection of capital markets facing the banks, the basic loan supply equation (2) is augmented as follows.

$$
\begin{gathered}
\frac{F L_{t}}{D_{t-1}+C A P_{t-1}}-\left(1+r_{t+1}\right)^{-1}\left(\frac{F L_{t+1}}{D_{t}+C A P_{t}}\right)=\beta_{0}+\beta_{1}\left(1+r_{t+1}\right)^{-1} \\
+\beta_{2}\left(1+r_{t+1}\right)^{-1}\left(r_{L, t+1}-r_{C, t+1}\right)+\beta_{3}\left(1+r_{t+1}\right)^{-1} \frac{p_{t}^{L}}{p_{t-1}^{L}}+\beta_{4} \frac{\Delta D_{t}}{D_{t-1}}+v_{t+1} \\
\text { where } \quad \beta_{1}=\frac{\alpha_{0}-\alpha_{2}^{\prime}}{\alpha_{1}}-\mu \\
\beta_{3}=\frac{\alpha_{3}^{\prime}}{\alpha_{1}}
\end{gathered}
$$

Now we briefly discuss the identification problem. We term eq.(5) as loan supply equation, but some may argue that the land price is a proxy of future economic activity and appears in the demand equation of loans. Suppose that the loan demand equation is specified as a function of loan rate, rate of change in land price and activity level such as GDP or sales variable. Then it is easy to verify that both the loan supply equation (5) and the loan demand equation are overidentified. One of the key conditions for identification is the accessibility of call market only by financial institutions, which implies that the call rate does not appear in the loan demand equation.

Before proceeding to the formal analysis, let us have a brief look at the growth rate of deposits. Figure 7 shows the growth rate of deposits over 1977 to 1995 for each type of banks and Table 6 summarizes the average growth rate of deposits for the whole sample period as well as three subsample periods (1977-1986, 1987-1990 and 1991-1995). We observe spikes in the growth rate of deposits for 1982, 1985 and 1990, which are also found in the growth rate of loans 
in Figure 1. The growth rate of deposits fell sharply in 1991 and in actuality the averaged growth rate of deposits during 1991 to 1995 is negative for all types of banks but regional banks. A similar trend is also observed for the growth rate of loans. Since the level of deposits is mainly determined by the non-financial sectors and the banks take it as given, it seems that the movement of bank loans is quite affected by that of deposits. In fact the simple correlation coefficient between the growth rate of loans and that of deposits over the whole sample period is 0.8336, $0.6907,0.5921,0.6836$ for city banks, long-term credit banks, trust banks and regional banks, respectively. Further investigation into the relationship between bank loans and deposits will be made in the next section.

Lastly, the efficacy of regulation on bank capital is formally tested by adding the Lagrangean multiplier in either eq.(3) or (5). One caveat is that in general the Lagrangean multiplier per se is not observable, so that some proxy of the extent to which the regulation is binding should be employed instead. It is quite difficult to choose the relevant measure for this purpose. Therefore we decide to use the realized ratio of bank capital to total asset as a proxy. Whether the regulation is binding or not can be seen simply by testing the hypothesis that the coefficient of bank capital/total asset ratio is zero. ${ }^{14}$

\section{B. Estimation Method}

The loan supply equations are estimated by the generalized method of moments (GMM) technique originally developed by Hansen(1982). We get rid of firm-specific effects by first differencing equations, as is suggested by Anderson and Hsiao(1981). Under the assumption of rational expectations, candidate for the instruments for the first-differenced form should be the variables included in the information set in period t-1. Our basic list of instruments in estimation includes constant term, twice lagged first-differenced LHS variable, $\Delta\left(1+r_{t+1}\right)^{-1}$, $\Delta\left(1+r_{t+1}\right)^{-1}\left(r_{L, t+1}-r_{C, t+1}\right)$ and thrice lagged $\Delta\left(1+r_{t+1}\right)^{-1}\left(r_{L, t+1}-r_{C, t+1}\right)$. The twice lagged first- differenced GDP growth rate is also included as an instrument to account for the determinant of loan demand. The twice and thrice lagged variables of $p_{t}^{L} / p_{t-1}^{L}$ are added as instruments to estimate the loan supply equation with the land price as explanatory variable. On the other hand, the twice and thrice lagged variables of $\Delta D_{t} / D_{t}$ are added as instruments to estimate the loan supply equation with the growth rate of deposit as explanatory variable. 


\section{Data Set Description}

The loan supply equations are estimated on the basis of panel data set of Japanese commercial banks, which is taken from the Nikkei NEEDS Company Data Base. Our panel data set consists of 139 banks for the period of 1976 to 1995 . There are 7 city banks, 3 long-term credit banks, 7 trust banks and 122 regional banks. It should be noted that the regional banks are quite different from major banks in terms of size, loan customers, position in the inter-bank markets and so forth. Table 7 compares the selective figures from the banks' balance sheets between major banks and regional banks based on our panel data set. They are the sample mean for the period of fiscal year 1976 to 1995 . The sample mean of total assets is 1,285 billion yen for regional banks and 16,091 billion yen for major banks, which is 12.5 times as large as that of regional banks. The stock of call loan is larger than that of call money borrowing for regional banks, but the opposite is true for major banks. It implies that in general the regional banks supply the surplus fund to the call market, while major banks raise the fund in need there. More than half of the total liabilities is time deposits for regional banks, but it is only $30 \%$ for major banks. However the proportion of certificate of deposits (CD) in total liabilities is higher for major banks $(2.88 \%)$ than that of regional banks $(0.83 \%)$. To sum up, comparison between the two types of banks suggests that it will be desirable to conduct the empirical analysis separately for major banks and regional banks.

We also conduct the subsequent analysis by disaggregating loans in two manners. First, loans are divided into those to small firms and to large firms. As was seen in the previous section, the banks have increasingly put more weight on small firms in making loans that are relatively new customers to the banks. Therefore we conjecture that the degree of asymmetry in information between lenders and borrowers will be more severe for small firms, which might be reflected on the lending behavior of banking firms.

We also disaggregate loans into those to manufacturing industries and non-manufacturing industries. As was seen in the previous section, the proportion of loans to non-manufacturing industries exhibited an increasing trend over the 1980's, especially in the bubble period. The growth pattern of non-manufacturing industries is quite different from that of manufacturing industries. Hence the tilt of bank loans toward non-manufacturing industries might reflect the 
changing industry structure in the Japanese economy. Estimating loan supply equations separately for manufacturing industries and non-manufacturing industries has the merit to control these demand-side conditions of loans.

Description of the variables used for estimation is now in order. The loans and deposits variables are taken from the balance sheet of banks. ${ }^{15}$ The size of bank is defined as the sum of deposits, bank debentures, and bank capital. The flow of loans and deposits are simply calculated as the current end-of-fiscal-year stock minus the end-of-fiscal-year stock in the previous year. The interest rate on loans is computed as the interest receipts on loans and discounts divided by the end-of-fiscal-year loan stock in the previous year. The required rate of return and the call rate are the average of the government bond yields listed on Tokyo Stock Exchange(10 year) and collateralized overnight call rate, respectively, over the fiscal year. We assume that all the banks face the same required rate of return and the call rate. As for the land price, it is assumed that the banks face different land prices, depending on the location of their head offices. When they are located in the prefectures of Tokyo, Kanagawa, Saitama, Chiba, Aichi, Osaka, Kyoto, Hyogo, Nara, and Wakayama, we use the land price index of six largest cities. ${ }^{16}$ For the other locations, we use the land price index of the other cities except six largest cities. They are taken from Japan Research Institute of Real Estate.

\section{Estimation Results and Interpretations}

\section{Total Loans}

The basic loan supply equation (3) is estimated separately for major banks and regional banks with the ratio of total loans to the bank size as dependent variable. The estimation is conducted for the whole sample period, 1981-1994 as well as three subsample periods: 19811986, 1987-1990 and 1991-1994. ${ }^{17}$ The 1987-90 period corresponds to the bubble period when asset prices soared, while the 1991-94 period corresponds to the period when the bubble burst. By dividing the whole sample period into three, it is expected that we may capture the different responses of bank lending to the change in economic conditions.

The estimation results of the basic loan supply equation are not satisfactory on the whole. For major banks the interest rate differential exerts a significantly positive effect on the loan supply irrespective of the sample period chosen. For regional banks the coefficients of the 
interest rate differential are also significantly positive except for the period of 1987-1990 and 1991-1995. However the J-statistics indicates that overidentifying restrictions are rejected at the standard level for all the cases but the 1991-1995 regression for major banks. This evidence hints that the interest rate differential alone cannot adequately explain the growth rate of loans and that the basic model is misspecified.

Table 8 shows the estimation results of eq.(4), extended version of eq.(3). We first examine the estimation results for major banks, which are shown in Table 8-1. When the loan supply equation is estimated over the whole sample period, the interest rate differential as well as the growth rate of deposits has positive and significant coefficients. The overidentifying restrictions are satisfied for the case where both the rate of change in land price and the growth rater of deposit are included as explanatory variables. Surprisingly the rate of change in land price picked up the wrong sign and that significant. However, once the sample period is divided into three, a different story shows up. For the period of 1981-1986 all the explanatory variables including the rate of change in land price are significant and that the overidentifying restrictions are not rejected. For the period of 1987-1990 both the rate of change in land price and the growth rate of deposits have positive effects on loan supply and they are significant. For the period of 1991-1994 the rate of change in land price loses its significance, but the interest differential as well as the growth rate of deposits keeps their significance. ${ }^{18}$

To sum up the results, the rate of change in land price is a significant variable for the period of 1981-1986 and 1987-1990. Moreover the coefficient of land price change in the period of $1987-1990$ is larger than that in the period of $1981-1986$ by $32 \%$ for the case where all the regressors are employed. The coefficient of the growth rate of deposits is positive and significant irrespective of the sample period. It indicates that the major banks face imperfect capital market, although the degree of imperfection was somewhat alleviated in the period of 1991-1994. The interest rate differential is significant except for the bubble period. Since the interest differential is the fundamental variable to measures the profitability of lending activities, we can infer that the lending behavior of city banks in the bubble period was somewhat different from that in the other periods judging from the negative sign of the interest differential.

Now we discuss the estimation results for regional banks, which are shown in Table 8-2. When the loan supply equation is estimated over the whole sample period, either the growth rate 
of deposits or the interest differential is significant, but the overidentifying restrictions are decisively rejected. Turning to the estimation results for the three subsample periods, the growth rate of deposits exerts positive and significant effect on loan supply for the period of 1976-86. Moreover, the overidentifying restrictions are not rejected when all the regressors are taken together. For the period of 1987-1990 as well as 1991-1994 all the explanatory variables gain statistical significance and the overidentifying restrictions are not rejected. Note that the growth rate of deposits remains significant irrespective of the sample period chosen. Furthermore the coefficient estimates of the growth rate of deposits for regional banks are larger in size than those for major banks for most of the cases. This evidence suggests that regional banks are more vulnerable to the shocks to deposits and hence their lending behavior is affected much more sensitively by the deposit shocks. In other words, regional banks are constrained in the capital market much more severely than major banks.

Contrasted with the response of bank loans to deposits, the coefficient estimates of the rate of change in land price is larger for major banks. As was seen in the previous section, the shift of bank loans to small and/or non-manufacturing firms is more noticeable for major banks than for regional banks. It implies that major banks are likely to make loan contract with relatively new customers the information of which has not been accumulated within the banks, so that collateral will play a more important role. This can explain why the loans by major banks are more responsive to land price. We scrutinize this conjecture by estimating the Euler equation separately for loans by firm size and by industries.

\section{Loans by Firm Size}

First we estimate the basic loan supply equation (3) separately for loans to small firms and large firms. Two loan supply equations are jointly estimated. The coefficient estimates of the interest differential are shown in Table 9. For major banks the coefficient of interest rate differential is significantly positive for all the subsample periods irrespective of firm size. The overidentifying restrictions are not rejected at the 5\% significance level for the period of 1987 1990 and 1991-94. For regional banks some of the interest differential coefficients are significantly positive, but the overidentifying restrictions are decisively rejected for all the cases.

Table 10-1 shows the estimation results of the extended version, eq. (4) for major banks. 
Although the rate of change in land price pick up the wrong sign and the overidentifying restrictions are rejected for all the cases over the whole sample period, we can detect an interesting pattern of lending behavior once the sample period is split into three. This suggests that the pattern of lending behavior for major banks is changing over time and that estimation of the Euler equation without proper consideration for the sample period might lead to misunderstanding of the bank's behavior. For the period of 1981-1986 the interest differential has significantly positive effects on both small firm and large firm loans. Besides the interest differential, the rate of change in land price as well as the growth rate of deposits are positive and significant for loans to large firms. Moreover the overidentifying restrictions are not rejected at the $5 \%$ significance level when all the regressors are taken into consideration. For the period of 1987-1990 the growth rate of deposits are positive and significant for both types of loans, but the rate of change in land price remains significant only for the loans to small firms when all the regressors are included in regression. For the period of 1991-1994 both the interest differential and the growth rate of deposits have significantly positive effect on the loans to large firms, but we cannot detect any significant explanatory variables for the loans to small firms. Note that in the bubble period the rate of change in land price has significantly positive effect on loans to small firms, but not to large firms. This evidence seems to support our conjecture that real estate is more potent as collateral in lowering the cost associated with asymmetric information for loans to borrowers with shorter customer relationship. ${ }^{19}$

Table 10-2 shows the estimation results of loan supply equations by firm size for regional banks. Over the whole sample period the growth rate of deposits is the only significant variable in the loan supply equation to small firms and none of the explanatory variables can explain the loans to large firms satisfactorily. Moreover, the overidentifying restrictions are decisively rejected. By dividing the sample periods into three, we find that the growth rate of deposits has always positive and significant effects on loans to small firms. To the contrary, the growth rate of deposits is not significant in the loan supply equation to large firms. In addition to the growth rate of deposits, both the rate of change in land price and the interest differential exert significantly positive effects on loans to small firms in the period of 1987-90. To sum up, we see that it is the growth rate of deposits that matters for loans to small firms by regional banks. Moreover, in the bubble period land also played a collateral role in lending to small firms and 
mitigated the problem of asymmetric information between lenders and borrowers.

\section{Loans by Industries}

Here we estimate the loan supply equation by industries. In particular we divide the total loans to manufacturing and non-manufacturing industries. The virtue of estimating the loan supply equation separately for different industries is to control the demand-side conditions of loans. It is also expected that we may see how the banks supplied loans in response to the changing industrial structure. First, the basic loan supply equation (3) is estimated jointly for loans to manufacturing and non-manufacturing industries. For major banks we obtain positive and significant coefficients of the interest differential for loans to non-manufacturing industries, but we fail to obtain significantly positive coefficients for loans to manufacturing industries. Moreover, the overidentifying restrictions are rejected for all the subperiods but the period of 1987-90. For regional banks the interest differentials affected the loan supply to manufacturing industries as well as non-manufacturing industries in a significantly positive manner for most of the subperiods, but the overidentifying restrictions are rejected for all the cases.

Next, we estimate the extended version of the loan supply function. The estimation results are shown in Table 11. Table 11-1 shows the results for major banks. When the loan supply equation is estimated over the whole sample period, we find that some coefficients of the interest differential and the growth rate of deposits are significantly positive, although the overidentifying restrictions are rejected in all the cases. This again hints the need to estimate the loan supply equation by dividing the sample period into the subperiods. For loans to nonmanufacturing industries, it turns out that the growth rate of deposits has always positive and significant effects on loan supply. Furthermore, the rate of change in land price gains its significance in the period of 1981-86 and 1987-1990. Note that the coefficient of land price change in the period of 1987-1990 is 2.6 times as large as that in the period of 1981-86 for the case where all the explanatory variables are taken into consideration. The interest differential is also positive and significant for the period of 1981-86 and 1991-94. To the contrary, we cannot detect meaningful explanatory variables for loan supply to manufacturing industries except for the land price change in the period of 1991-94.

Table 11-2 shows the estimation results of loan supply equation by industry for regional 
banks. When it is estimated over the whole sample period, some of the coefficients satisfy the sign conditions the theory requires, but the rejection of overidentifying restrictions indicate that the model is misspecified. When we estimate the loan supply equation for the subsample periods, we obtain much more reasonable coefficient estimates. For loans to non-manufacturing industries, we obtain positive and significant coefficients on both the growth rate of deposits and the interest differential irrespective of the sample period. In addition to these explanatory variables, the rate of change in land price has positive and significant effect on loans in the period of 1987-90. For loans to manufacturing industries, the coefficients of the growth rate of deposits is positive and significant for the period of 1981-86, and the interest differential as well as the land price change has positive and significant effects on loan supply for the period of 1991-94. However, none of the explanatory variables are economically meaningful in the period of 1987-90.

What are common to lending to non-manufacturing industries by major banks and regional banks is the sensitivity of loans to deposits irrespective of the subsample periods and the positive response of loans to the land price appreciation in the bubble period. Note that the response loans to land price change by major banks is much larger than that by regional banks. This is consistent with our early observation that the shift of loans toward non-manufacturing industries is much more rapid for major banks than for regional banks and hence major banks are more liable to the problem of asymmetric information.

\section{Effect of Basle Accord on Lending Behavior}

Lastly we examine the introduction of regulation on bank capital that took full effect in March in 1993 (The Basle Accord). According to the Accord, the banks should keep the ratio of bank capital to risk-weighted assets above $8 \%$ for banks dealing with international business. When this condition is binding, the positive Lagrangean multiplier does appear as an additional factor to affect the growth rate of loans (Recall eq.(2)).

To test whether the Basle Accord affects the lending behavior of banks, we reestimate the Euler equation by adding the variable closely correlated with the level of Lagrangean multiplier since the Lagrangean multiplier per se is not observable. Our candidate for the proxy of the multiplier is an observed ratio of bank capital to bank assets. The ratio of bank capital to riskadjusted bank assets on the basis of BIS standard is available for the banks that have international 
operations since 1989, when the capital requirements became effective. Therefore, we reestimate the loan supply equation with the bank capital ratio as an additional explanatory variable for the period of 1992-1994. Now the sample banks are reduced from 139 to $82 .{ }^{20}$ The estimation of loan supply equation is conducted not only for total loans but also for loans by firm size and industries. The estimation results are shown in Table 12.

The ratio of bank capital to bank assets has positive and significant effects on the lending behavior of major banks, but not that of regional banks. That is, when the ratio of bank capital to bank assets is lowered for some reasons, the major banks will decrease lending. Our results that the capital requirement was binding in terms of lending behavior only for major banks with active international business are consistent with the findings of Ito and Sasaki(1998).

When the loans are further broken down into those to small firms and large firms, it is seen that the bank capital ratio exerts significantly positive effects on loans to large firms, but not to small firms. We also find that the bank capital ratio has larger positive effects on loans to nonmanufacturing industries. When the bank capital ratio falls, we also observe the reallocation of loans by regional banks from manufacturing firms to non-manufacturing firms even though the total loan volume is unaffected.

7.Bank Lending and Its Macroeconomic Consequences: Evidence from the Estimation of Investment Function

In the previous sections we obtained the evidence that loans to small and/or nonmanufacturing firms were quite sensitive to the shocks in asset markets. In the bubble period the loans to small and/or non-manufacturing firms by major banks were very much affected by a change of land price that affected the collateral value. The loans to small and non-manufacturing firms by regional banks were quite sensitive to the change in deposits irrespective of the period chosen.

Note that our evidence has very important implications as to the propagation mechanism of shocks in the financial sector into the real economy. Suppose that a negative shock hits the banking sector. Then major banks as well as regional banks will cut loans to small and/or nonmanufacturing firms more severely than to large firms and/or manufacturing firms. If the firms hit by the loan cut do not have substitutes for bank loans, it will directly affect the investment 
activity of those firms. This is the point to be examined in the subsequent sections.

Our empirical strategy is to measure the sensitivity of fixed investment to bank loans by industry and firm size. The sensitivity of investment to bank loans can measure the degree of substitutability among alternative financing method. It is conjectured that investment by smaller firms is more sensitive to bank loans since they have much fewer alternatives to bank loans in raising the funds. Therefore we estimate the investment function by industry and firm size.

First, let us state the basic framework of investment function. We assume that there are two types of firms in the economy. One type is the firm without any constraints in the capital market. For this type of firm, investment is determined solely by the fundamental profitability of investment, which is measured by Tobin's marginal q. It is defined as the expected present value of the future marginal products of capital divided by capital stock. The other type of firm faces borrowing constraints. The level of investment for this type of firm is determined by the availability of bank loans, which is measured by the growth rate of loans. For this type of firms, investment will not increase even if the future profitability of investment improves, since the firms cannot finance the investment expenditure. It is only when the loan supply to these firms increases that they increase investment spending. Note that increase of loan supply will not affect the investment activities of unconstrained firms as long as the future profitability of investment is unchanged.

The aggregate investment is thus determined by two factors: the marginal $\mathrm{q}$ and the growth rate of loans. To account for the delayed response of investment to these two factors, we introduce the distributed lags in specifying the effects of the two factors on investment. We also add the lagged investment rate to cope with the nonstationarity of investment rate. The investment function to be estimated is written as:

$$
\frac{I_{t}}{K_{t-1}}=\gamma_{0}+\sum_{i=0}^{N} \gamma_{1, i} M q_{t-i}+\sum_{i=0}^{N} \gamma_{2, i} \frac{\Delta L_{t-i-1}}{L_{t-i-2}}+\gamma_{3} \frac{I_{t-1}}{K_{t-2}}+u_{t}
$$

where $I_{t}$ : gross fixed investment in period $\mathrm{t}$

$K_{t-1}$ : capital stock at the end of period t-1

$M q_{t}:$ marginal $\mathrm{q}$ in period $\mathrm{t}$

$L_{t}$ : loan outstanding at the end of period $\mathrm{t}$ 


$$
u_{t}: \text { disturbance term }
$$

The coefficients of the growth rate of loans measure the extent to which bank loans can be substituted for another financing method. We exclude the current growth rate of loans from the explanatory variables to avoid the simultaneity problem of loan demand and investment. Therefore it is expected that the growth rate of loans in eq.(6) can measure the effects of loan supply on investment. ${ }^{21}$

The series of marginal $\mathrm{q}$ is constructed in the following manner. First, the stochastic properties of the two components of marginal q, the profit rate and the discount factor, are examined. The profit rate is constructed as the ratio of operation surplus to the beginning-ofperiod capital stock. The discount factor is computed as $(1-$ depreciation rate $) /(1+$ borrowing interest rate) where the depreciation rate is assumed to be constant, $1.98 \%$ per quarter, across industries. ${ }^{22}$ The unit root test is conducted for these two series and we detect unit roots for all the series in manufacturing and non-manufacturing industries. Next we test the cointegration relationship between the profit rate and the discount factor and find no cointegration relationship. Therefore it is assumed that these two series follow the VAR model in first-difference form. Finally, based on the VAR estimates, we construct the marginal q series. ${ }^{23}$

Figure 8 depicts the constructed series of marginal q from the fourth quarter of 1975 to the first quarter of 1998. Figure 8-1 shows the marginal q of manufacturing industries by firm size. The level of marginal $\mathrm{q}$ is higher for small firms than for medium and large firms for most of the period. We observe two peaks in marginal q for small firm group in 1979 and 1989, each of which corresponds to the peaks in investment rate. The marginal q falls sharply from 1991 to 1994 after the burst of the bubble. The marginal q series of medium and large firm groups are very much alike and much smoother than that of small firm group. Figure 8-2 shows the marginal q of non-manufacturing industries. Here we also observe two peaks in 1979 and 1989 for small firm group. The marginal q series of medium and large firm group move very closely each other and much smoother than that of small firm group.

Table 13 shows the sample average of the marginal q over the whole sample period as well as three subperiods: the fourth quarter of 1975 to the fourth quarter of 1986, the first quarter of 1987 to the first quarter of 1991 , and the second quarter of 1991 to the first quarter of 1998 . The 
marginal $\mathrm{q}$ is highest in the second subperiod for small firm group of manufacturing as well as non-manufacturing industries. On the other hand, the marginal q series of medium and large firms in the bubble period are not discernibly difference from those before the bubble period. However, the marginal $\mathrm{q}$ is lowest in the third subperiod irrespective of firm size and industry, hinting how severe the downturns are after the burst of the bubble. Note that the volatility of marginal $\mathrm{q}$ in terms of standard deviation is highest in small firm group of both manufacturing and non-manufacturing industries.

Eq.(6) is estimated separately for each firm size group and industry by applying the Almon lag procedure. The lag length is taken to be 16 quarters .The estimation results are shown in Table 14. The coefficient estimates in table show the sum of lagged coefficients of marginal $\mathrm{q}$ and loan growth rate. The coefficients of marginal $q$ are positive and significant for all the cases but large firm group in non-manufacturing industries. The coefficients of the growth rate of loan are significantly positive for small firm group in both manufacturing and non-manufacturing industries, medium firm group in manufacturing industries, and large firm group in nonmanufacturing industries. ${ }^{24}$ It should be noted that the non-negligible proportion of small firms in manufacturing as well as non-manufacturing industries are constrained in the capital market and that their investment is bound by the availability of bank loans. ${ }^{25}$

Our evidence confirms our conjecture that smaller firms do not have substitutes for bank loans, so that their investment activities are much more affected by a shock in the financial sector. To assess the importance of bank loans to firms' investment behavior quantitatively, we evaluate the extent to which the shocks of bank loan supply affect firms' investment activities by simulation technique. Before proceeding to the formal analysis, we first show descriptively how two financial events leading to the change in lending attitude of banks affected the actual loan amount. One event is the introduction of restrictions on bank lending to real estate industry that took effect in April in 1990 and lasted until December in 1991. The other is the failure of large financial corporations in November in 1997. The empirical strategy is very simple. We compute the average growth rate of loans over the three years prior to the event and then subtract the averaged growth thus computed from the actual growth rate after the event. What is computing is the deviation of the growth rate of loans from the recent trend and it shows the effects of the event on actual loan growth. 
Figure 9 shows the effects of bank loan restriction on real estate industry on actual loan amount from the second quarter of 1990 to the second quarter of 1993. The introduction of regulations had large negative effects on the growth rates of loans to non-manufacturing firms, irrespective of firm size. The growth rate of loans was lowered from 1991 on. The growth rate of loans of small firms in manufacturing industries was also reduced from 1992 on. It should be noted that the growth rate of loans increased considerably for large firms in manufacturing industries. This indicates that banks shifted loans from non-manufacturing industries to large firms in manufacturing industries.

Table 15 shows the effects of bank failures in November in 1997 on the growth rate of loans. It is also seen that the actual growth rate of loans to small firms was hit severely by this incidence. For small firms in non-manufacturing industries, the loan growth rate was decreased by $1.2 \%$ and $2.1 \%$ per quarter in the last quarter of 1997 and the first quarter of 1998 , while it was reduced by $1 \%$ per quarter in the first quarter of 1998 for small firms in manufacturing industries.

Now we simulate the effects of bank lending on firms' investment expenditure. Two simulation exercises are conducted. One is to measure the effects of loan supply contraction in the early 90's on firms' investment. The discount rate was raised as many as five times from May in 1989 to September in 1990. Furthermore, as was mentioned above, restrictions of bank loans to real estate industry took effect in April in 1990 and lasted until December in 1991. This tight monetary policy reduced loan supply to a large extent. The other is the failure of big financial institutions in autumn in 1997. As was seen above, banks became very cautious in lending, especially to small firms, after this financial turmoil.

The effects of loan supply cut on investment expenditure in these two cases are examined as follows: First, we simulate the model consisting of the investment function and the capital stock identity over the period we are interested in. Then we simulate under the alternative lending scenario. Specifically, we compute the average growth rate of loans over the several quarters prior to the simulation period and use it as the alternative. We can measure the effects of loan supply cut on investment by subtracting the benchmark solution of investment from the solution under the alternative scenario.

In the first exercise, the simulation period covers from the third quarter of 1991 to the 
second quarter of 1993. The simulation results are shown in Table 16. It shows in billion yen and percentage terms how much investment spending would have been changed if the lending behavior had not been changed. To obtain the aggregate change in investment, we assume that the rest of investment spending not covered by our sample changes as the same proportion as the small firm group in non-manufacturing industries. This assumption will be justified since the rest of investment mainly comes from small businesses that are not incorporated. The aggregated investment would have been increased by about 3 trillion yen or by $15 \%$ per quarter in the first and second quarter in 1993. When the effects are disaggregated, we see that the effects are centered on non-manufacturing industries, especially on small firm group. The investment increase amounts to 650 to 700 billion yen in the first and the second quarter of 1993 for small and large firm groups of non-manufacturing industries. In percentage terms the investment would have been increased by 25 to $30 \%$ in the same quarters in 1993 for small and medium firm groups of non-manufacturing industries. Our results are quite contrasted with the findings of Motonishi and Yoshikawa(1998). They report that a significant fall of investment during 1992-94 is basically caused by worsening real factors rather than financial factors. Their results are based on the investment function using the Bank of Japan diffusion indices of 'real profitability' and 'banks' willingness to lend.' To evaluate their assertions in our model, we conduct another simulation exercise where the averaged marginal q over the two years prior to the simulation period is used instead of the actual figures. The difference in investment between the alternative and the benchmark is shown in Table 17. The aggregate investment would have been increased by 4.5 to 5.1 trillion yen or by $23-27 \%$ in the first and second quarters in 1993 . These figures are larger than those in the previous bank lending simulation, but not so overwhelming. The figures in 1991 to 1992 are more or less the same as those in the bank lending simulation. Furthermore, the effects of bank lending on investment in non-manufacturing industries are at least as large as those of real factor on investment. The difference between their results and ours appears to be mainly due to the choice of explanatory variables in investment function. The diffusion indices, their explanatory variables, give some distributional information across firms on profitability or evaluation of the lending attitude of financial institutions. However, it is not so clear how they are associated with the traditional explanatory variables such as marginal q, sales or interest rate.

Lastly, we examine the effects of successive failures of financial institutions or credit 
crunch in November in 1997 on investment activities. The simulation period covers from the second quarter of 1996 to the first quarter of 1998. The alternative scenario is based on the premise that the average growth rate of loans over the first quarter of 1995 to the first quarter of 1996 continues over the simulation period. This period corresponds to the short-lived recovery of the economy. The difference in investment between the alternative and the benchmark is shown in Table 18. The aggregate investment would have been expanded by 1.6 and 1.9 trillion-yen or by $7.4 \%$ and $9.3 \%$ in the last quarter of 1997 and the first quarter of 1998, respectively. It should be noted that the effects of credit crunch fall mostly on small firms in non-manufacturing industries. Their investment would have been increased by around 300 billion-yen or $15-20 \%$ in that period. ${ }^{26}$

To sum up, lending channel does exist in Japan and in particular small firms are quite vulnerable to the shocks in asset markets.

\section{Concluding Remarks}

We examined the role of bank loans in the Japanese economy by analyzing the lending behavior of banks and the investment behavior of borrowers.

We could explain successfully the lending behavior of Japanese banking firms by splitting the sample period into three: the pre-bubble period(1976-1986), the bubble period(1987-1990), and the post-bubble period(1991-1995). Our main findings are that the lending behavior is quite different by types of banks and of borrowers. For regional banks the bank loans are more sensitive to deposits. It implies that the degree of capital market imperfections is more severe for regional banks and that the shocks to the balance sheet of regional banks cannot be completely offset by the adjustment of portfolio. For major banks real estate plays a more vital role as collateral in loan contracts. We also find that real estate is more important for lending to small and/or non-manufacturing firms. The share of small and/or non-manufacturing firms in total loans has increased constantly. Therefore real estate functioned as a device to reduce the agency cost stemming from the asymmetric information between the new borrowers and banks. It is also notable that loans to small and/or non-manufacturing firms are more sensitive to the shocks in deposits.

As for the findings on the real side of the economy, we find that expenditure on fixed 
investment is more sensitive to bank loans for smaller firms that do not have close substitute for bank loans. In particular our simulation exercises demonstrate that cut of loans supply is largely responsible for the stagnancy of investment in the downturns after the burst of the bubble and the financial turmoil in 1997.

Our findings are quite useful in designing the stabilizing policy of the real economy. Due to the inability to offset the shocks to the balance sheet of relatively small banks such as regional banks, the shocks in the financial sector are easily propagated into the real economy. Since the customers of small banks are also small in size, they do not have substitutes for bank loans and thus their activity is directly affected by bank lending.

Shocks to asset prices, notably land price, also affect the supply of loans to small firms by large banks by way of changing the collateral value. This dependence of bank loans on the collateral value also makes the loans to small firms more sensitive to the shocks in the asset markets. In particular small firms are more likely to be constrained in credit markets in recession.

To sum up, the effects of tight credit conditions or financial distress fall disproportionately on small firms. This distributional aspect should be borne in mind in implementing the stabilization policy. Recognizing this problem, the government expanded the amount of credit insurance to small firms by 20 trillion in October in 1998. It is expected that bank loans are channeled to the small firms in need of funds in an efficient manner by this policy. 


\section{Mathematical Appendix}

- Derivation of Optimal Loan Supply Equation (2) -

The banking firm chooses the optimal level of bank loans, call money and security holdings given the level of deposit and bank capital so that the value of firm can be maximized. The banking firm is subject to two constraints: reserve requirement on deposits and minimum requirement on the ratio of bank capital to bank assets. The value of banking firm $\left(V_{t}\right)$ is defined as the discounted sum of future net cash flow. In other words,

$$
V_{t}=E_{t}\left[\sum_{j=0}^{\infty} \gamma_{t+j} \Psi_{t+j}\right]
$$

$$
\begin{aligned}
& \text { where } \gamma_{t+j}=\prod_{i=1}^{j}\left(1+r_{t+i}\right)^{-1} \quad(j=1,2, \cdots) \gamma_{t} \equiv 1 \\
& \Psi_{t}: \text { net cash flow in period } \mathrm{t}, \text { defined as } \\
& \Psi_{t}=r_{L, t} L_{t-1}+r_{S, t} S_{t-1}-r_{C, t} C L_{t-1}-r_{D, t} D_{t-1}-C\left(F L_{t}, L_{t-1}, D_{t-1}+C A P_{t-1}\right) \\
& r_{t+1}: \text { one-period required rate of return in period } \mathrm{t}+1 \\
& \gamma_{t+1}: \text { discount factor in period } \mathrm{t}+1 \\
& r_{L, t}: \text { interest rate on bank loans in period } \mathrm{t} \\
& r_{S, t}: \text { interest rate on securities in period } \mathrm{t} \\
& r_{C, t}: \text { call rate in period } \mathrm{t} \\
& r_{D, t}: \text { interest rate on deposits in period } \mathrm{t} \\
& L_{t-1}: \text { loan stock at the end of period } \mathrm{t}-1 \\
& S_{t-1}: \text { securities stock at the end of period } \mathrm{t}-1 \\
& C L_{t-1}: \text { stock of call money borrowing or loans at the end of period } \mathrm{t}-1 \\
& D_{t-1}: \text { deposit stock at the end of period t-1 } \\
& F L_{t}: \text { net flow of bank loans in period t } \\
& C\left(F L_{t}, L_{t-1}, D_{t-1}+C A P_{t-1}\right): \text { loan-related cost function } \\
& C A P_{t-1}: \text { bank capital at the end of period t-1 }
\end{aligned}
$$




\section{$E_{t}[\cdot]$ : mathematical expectation operator conditional on the information available in period $t$}

The loan-related cost function, $C\left(F L_{t}, L_{t-1}, D_{t-1}+C A P_{t-1}\right)$ has the property that $\partial C / \partial F L_{t}>0, \quad \partial C / \partial L_{t-1}>0, \partial C / \partial\left(D_{t-1}+C A P_{t-1}\right)<0$ and $\partial^{2} C / \partial F L_{t-1}^{2}>0$.

The two constraints facing the banking firm is expressed as follows:

$$
\begin{aligned}
& R R_{t} \geq k D_{t} \\
& C A P_{t} \geq q L_{t} \\
& \text { where } R R_{t}: \text { reserves } \\
& k: \text { minimum reserve requirement ratio } \\
& \quad q: \text { minimum required ratio of bank capital to loans }
\end{aligned}
$$

The balance sheet identity for the banking firm is written as

$$
R R_{t}+L_{t}+S_{t}=D_{t}+C L_{t}+C A P_{t}
$$

The relationship between stock and flow of the assets is expressed as

$$
\begin{aligned}
& L_{t}=L_{t-1}+F L_{t} \\
& S_{t}=S_{t-1}+F S_{t} \\
& C L_{t}=C L_{t-1}+F C L_{t}
\end{aligned}
$$

where $F S_{t}$ : flow of securities holdings in period $\mathrm{t}$ $F C L_{t}$ : flow of call money borrowing or loans in period $\mathrm{t}$ 
In what follows we assume that the banking firm will hold minimum balance of required reserves since it bears no interest. In other words,

$$
R R_{t}=k D_{t}
$$

Maximization of eq.(A-1) subject to eqs.(A-3) to (A-8) yields the following first order condition for bank loans:

$$
E_{t}\left[\left(1+r_{t+1}\right)^{-1}\left\{r_{L, t+1}-r_{C, t+1}-\frac{\partial C}{\partial L_{t}}+\frac{\partial C}{\partial F L_{t+1}}\right\}\right]-\lambda_{t} q-\frac{\partial C}{\partial F L_{t}}=0
$$

where $\lambda_{t}$ : non-negative Lagrangean multiplier associated with the requirement on bank capital

Substituting the loan-related cost function (eq.(1)) in the text into eq.(A-9) and arranging terms, we obtain the following optimal loan supply equation.

$$
\begin{gathered}
\frac{F L_{t}}{D_{t-1}+C A P_{t-1}}=\beta_{0}+\beta_{1} E_{t}\left[\left(1+r_{t+1}\right)^{-1}\right]+\beta_{2} E_{t}\left[\left(1+r_{t+1}\right)^{-1}\left(r_{L, t+1}-r_{C, t+1}\right)\right] \\
-\frac{q}{\alpha_{1}} \lambda_{t}+E_{t}\left[\left(1+r_{t+1}\right)^{-1}\left(\frac{F L_{t+1}}{D_{t}+C A P_{t}}\right)\right] \\
\text { where } \beta_{0}=\mu-\frac{\alpha_{0}}{\alpha_{1}} \\
\beta_{1}=\frac{\alpha_{0}-\alpha_{2}}{\alpha_{1}}-\mu \\
\beta_{2}=\frac{1}{\alpha_{1}}
\end{gathered}
$$

The final step to obtain the equation to be estimated is to decompose the conditional expectation 
terms in eq.(A-11) into the realized values and the forecast errors under the assumption that the banking firm forms expectations rationally. Then eq.(A-11) is rewritten as

$$
\begin{aligned}
\frac{F L_{t}}{D_{t-1}+C A P_{t-1}}-(1 & \left.+r_{t+1}\right)^{-1}\left(\frac{F L_{t+1}}{D_{t}+C A P_{t}}\right)=\beta_{0}+\beta_{1}\left(1+r_{t+1}\right)^{-1} \\
& +\beta_{2}\left(1+r_{t+1}\right)^{-1}\left(r_{L, t+1}-r_{C, t+1}\right)-\frac{q}{\alpha_{1}} \lambda_{t}+v_{t+1}
\end{aligned}
$$

where $v_{t+1}$ : forecast error

This is nothing but eq.(2) in the text. 


\section{Footnotes}

${ }^{1}$ The discussion on lending channel in the past is summarized in Kashyap and Stein(1994). Kashyap and Stein $(1995,1997)$ obtain the evidence supporting the lending channel for U.S. using the panel data of commercial banks. For the test of lending channel in Japan based on the time series data, see Ueda(1993), Miyagawa and Ishihara(1997), Hatakeda(1997), Hiroshima(1997), and Tanaka(1997).

${ }^{2}$ Sui(1995) is the only study in Japan to estimate the bank loan equations derived from the dynamic model of banking firms as far as the authors know, although he does not use panel data but quarterly aggregated data. As for the case of U.S., Elyasian et al. (1995) construct a dynamic model of bank behavior and estimate the optimal conditions for loans and deposits jointly based on the panel data of U.S. commercial banks.

${ }^{3}$ The member banks of the Second Association of Regional Banks are included in our definition of regional banks.

${ }^{4}$ Based on the time series data, Shimizu(1995), Yamazaki and Takeda(1996) and Ogawa and Kitasaka(1998) analyze the effect of real estate as collateral on bank lending.

${ }^{5}$ The original NEEDS Company Data Base includes 150 banks in total: 3 long-term credit banks, 11 city banks, and 129 regional banks including the member banks of the Second Association of Regional Banks. We exclude only 11 banks that experienced mergers during the sample period. They are Sakura bank, Asahi bank, Sumitomo bank, Tokai bank (4 city banks), Nishinippon bank, Michinoku bank, Sanin-Godo bank, Iyo bank, Kumamoto Family bank, Hokuto bank, and Akita Akebono bank (7 regional banks).

${ }^{6}$ Small firms are defined as the corporations with a capital less than 100 million yen or with regular employees less than 300 persons (wholesalers capitalized at less than 30 million yen or with regular employees less than 100 persons and retail trade, eating and drinking place and service industries capitalized at less than 10 million with regular employees less than 50 persons) and unincorporated enterprises.

${ }^{7}$ All the data series are seasonally adjusted by the Census X-12 ARIMA method. The detailed procedures for constructing the consistent data series are described in Ogawa (1999).

${ }^{8}$ The interest rate on time deposit had been regulated until 1993. Even after the uplift of regulation, the interest rate on deposits does not exhibit large variability across banks to induce shift of deposits. It justifies our assumption that deposit is exogenous to banks. The share price also had been stable until 1983, which discouraged banks from issuing new equities. This justifies our assumption that bank capital is exogenous to banks.

${ }^{9}$ As for the borrowings from the Bank of Japan, the official discount rate is usually set lower than the call rate, inter-bank market rate, so that we assume that the banking firm already borrows as much as possible from the Bank of Japan at the current discount rate.

${ }^{10}$ Note that call money borrowing refers to debit items of the banks, while call loan refers to credit items. In our model, call loan enters as a negative figure in debit items.

${ }^{11}$ Gross increase of loans is more closely associated with the agency cost than the net increase of 
loans given that all the new loans are for new customers. However, the unavailability of gross loan data forces us to use the flow loan data.

${ }^{12}$ In a static model, Yamazaki and Takeda(1997) include land price as a variable to affect the adjustment cost of loans and derive the optimal loan supply equation. It is shown that the optimal loan supply is a function of the interest differential between the loan rate and the call rate and the land price. Our model is interpreted as an extension of their model in the dynamic setting.

${ }^{13}$ Kashyap and Stein(1995) run a similar kind of regression of the growth rate of loans on that of core deposits.

14 Honda(1997) also investigates the implications of the Basle Accord using the panel data of banks as well as the quarterly aggregate data. Instead of estimating the structural equation, he estimates the reduced-form equation of bank loans. He finds that the introduction of the Basle Accord had significant impacts on bank credit. Moreover, it is found that the reaction of those banks with the international standard is significantly different from that with the domestic standard. Ito and Sasaki(1998) also examine how the Basle Accord influenced major Japanese banks' lending behavior between 1990 and 1993. They find that the effect of the risk-based capital (RBC) ratio on lending for city banks is positive and significant, but not different from zero for trust or regional banks. They conclude that the risk-based capital requirement was a serious hurdle only for banks with internationally active banks.

${ }^{15}$ The deposit variable we employ is core deposit excluding the CD's. We exclude the CD's since the banks can influence the interest and terms on the CD's. In testing the imperfection of capital market facing banks, we need the deposit variable exogenous to banks.

${ }^{16}$ The land price index of six largest cities is also applied to the prefectures adjacent to six largest cities, where the land price soared in the bubble period.

${ }^{17}$ The original sample period covers from 1976 to 1995 . However, the first five years are exclusively for instruments of 1981, while the last year is used as a lead variable in 1994 regression.

${ }^{18}$ The effects of the growth rate of deposits on bank loans are little affected even if the bank debentures are added to the deposit variable.

${ }^{19}$ Our evidence is consistent with the findings by Berger and Udell(1995) for the U.S. case. They find that borrowers with longer banking relationships are less likely to pledge collateral.

${ }^{20}$ The 82 banks include 7 city banks, 3 long-term banks, 7 trust banks, and 65 regional banks. We exclude the following sample (Hyogo bank in 1994) since the BIS standard capital-asset ratio is not reported for this year.

${ }^{21}$ Since the lagged investment rate is included in the regressors, the significance test of the deposit growth rates is equivalent to the Granger causality test from loan supply to investment. In the simulation analysis below we also show the evidence that the supply conditions of loans is very important in determining the observed growth rate of loans.

${ }^{22}$ See Data Appendix Table A-2 in Ogawa et. al (1994).

${ }^{23}$ See Abel and Blanchard(1986) for more details on the procedure to construct the marginal $\mathrm{q}$ series. 
${ }^{24}$ It might be argued that measurement error of the operating surplus, constituent of marginal q, is larger for small firms. If it is the case, then the coefficient estimates of investment function will be inconsistent. To account for measurement error of marginal q in small firm group, we employ the marginal q series of large firm group as instruments of marginal q in small firm group. It turns out that the coefficient estimates of marginal $\mathrm{q}$ and bank loan growth with $\mathrm{t}$-value in parentheses are $0.0079(1.01)$ and 0.1946 (2.34) for manufacturing industries and 0.0292 (3.40) and 0.1411 (1.93) for non-manufacturing industries, respectively. Although the marginal q loses its significance in manufacturing industries, all the other parameters remain significant.

${ }^{25}$ Our results are consistent with Motonishi and Yoshikawa (1998). They find that financial constraints are important for investment decision of small firms in manufacturing as well as nonmanufacturing industries.

${ }^{26}$ The annual growth rate of fixed investment would have been raised by $8.8 \%$ if the increment of investment in the first quarter of 1998 had continued throughout 1998. This is close to the figure obtained by Motonishi and Yoshikawa's study, 10\%. 


\section{References}

[1] Anderson, T.W. and C. Hsiao(1981)." Estimation of Dynamic Models with Error Components, Journal of the American Statistical Association 76, pp.598-606.

[2] Berger, A.N. and G.F. Udell(1995).” Relationship Lending and Lines of Credit in Small Firm Finance," Journal of Business Vol.68, No.3, pp.351-381.

[3] Elyasiani, E., Kopecky, K.J. and D. Van Hoose(1995)." Costs of Adjustment, Portfolio Separation, and the Dynamic Behavior of Bank Loans and Deposits, “Journal of Money, Credit, and Banking Vol.27, No.4, pp.955-974.

[4] Hansen, L.P.(1982)." Large Sample Properties of Generalized Method of Moments Estimator," Econometrica 50, pp.1029-1054.

[5] Hatakeda, T.(1997)." Nippon ni okeru Ginko Hakyu Keiro no Jyuyosei (On Importance of Bank Lending Channel in Japan)," Finance Kenkyu No.22, pp.15-31.

[6] Hiroshima, T.(1997)." Chushou Kigyo muke Kashidashi to Jittai Keizai Katsudo ni tsuite (Loans to Small Firms and Real Activity),” Working Paper 97-4, The Bank of Japan.

[7] Honda,Y.(1997)." Some Implications of the Basle Accord: The Case of Japan," mimeographed.

[8] Ito,T. and Y.N. Sasaki(1998)." Impacts of the Basle Capital Standard on Japanese Banks' Behavior," Discussion paper Series A No.356, The Institute of Economic Research, Hitotsubashi University.

[9] Kashyap, A.K. and J.C. Stein(1994).” Monetary Policy and Bank Lending," in Mankiw, N.G.(ed.), Monetary Policy, The University of Chicago Press, pp.221-256. 
[10] Kashyap, A.K. and J.C. Stein(1995)." The Impact of Monetary Policy on Bank Balance Sheets," Carnegie-Rochester Conference Series on Public Policy 42, pp.151-195.

[11] Kashyap, A.K. and J.C. Stein(1997)." What Do a Million Banks Have to Say about the Transmission of Monetary Policy?” NBER Working Paper No.6056.

[12] Miyagawa, T. and H. Ishihara(1997).” Kin’yu Seisaku $\square$ Ginko Kodo no Henka to Macro Keizai (Monetary Policy, Change in Bank Behavior and the Macroeconomy) in Asako, K., Yoshino, N. and S. Fukuda (eds.) Gendai Macro Keizai Bunseki, University of Tokyo Press, pp.157-191.

[13] Motonishi, T. and H. Yoshikawa(1998)." Causes of the Long Stagnation of Japan during the 1990's: Financial or Real?" mimeographed.

[14] Ogawa, K., Kitasaka, S.,Watanabe, T.,Maruyama, T.,Yamaoka, H. and Y. Iwata(1994). Asset Markets and Business Fluctuations in Japan, The Keizai Bunseki (The Economic Analysis), Economic Research Institute, Economic Planning Agency.

[15] Ogawa, K. and S. Kitasaka(1998) Shisan Shijyo to Keiki Hendo - Gendai Nippon Keizai no Jissho Bunseki (Asset Markets and Economic Fluctuations - An Empirical Analysis of Modern Japanese Economy), Nippon Keizai Shinbunsha.

[16] Ogawa, K.(1999)." Monetary policy, Credit and Real Activity: Evidence from the Balance Sheet of Japanese Firms,” mimeographed.

[17] Shimizu, Y.(1995)." Ginko no Jyoho Seisan to Tochi Tanpo Tsuki Kashidashi (Production of Information by Banks and Lending Secured by Land)," Business Review Vol.43, No.3, pp.52-66.

[18] Sui,Q.(1995).” Kin’yu Chukai Katsudo to Keiki Hendo (Financial Intermidiation and Business Fluctuations," Nippon Keizai Kenkyu No.29, pp.31-49. 
[19] Tanaka,K.(1997)." Ginko Shinyo to Kin’yu Seisaku no Koka (Bank Credit and Effects of Monetary Policy)," mimeographed.

[20] Ueda,K.(1993).” A Comparative Perspective on Japanese Monetary Policy: Short-Run Monetary Control and the Transmission Mechanism," in Singleton, K.J.(ed.) Japanese Monetary Policy, University of Chicago Press, pp.7-29.

[21] Yamazaki, F. and Y. Takeda (1997).” Tochi Tanpo no Kachi to Ginko no Kashidashi Kodo (The Collateral Value of Land and Bank Lending)," in Asako, K. and M. Otaki(eds.) Gendai Macro Keizai Dogaku, University of Tokyo Press, pp.351-375. 
Table 1 Summary Statistics: Growth Rate of Bank Loans

\begin{tabular}{|c|ccc|c|}
\hline & $1977-86$ & $1987-90$ & $1991-95$ & whole sample period \\
\hline city banks & 10.58 & 14.07 & 1.07 & 8.81 \\
$\begin{array}{c}\text { long-term } \\
\text { credit banks }\end{array}$ & 10.67 & 12.62 & -0.02 & 8.27 \\
trust banks & 10.17 & 11.31 & 0.06 & 7.75 \\
regional banks & 9.65 & 10.50 & 3.81 & 8.29 \\
total & 9.75 & 10.77 & 3.40 & 8.29 \\
\hline
\end{tabular}

Notes: The figures are average values of the sample period shown.

Source: Nikkei NEEDS Company Data Base

Table 2 Summary Statistics: Proportion of Bank Loans to Small Firms

$(\%)$

\begin{tabular}{|c|ccc|c|}
\hline & $1977-86$ & $1987-90$ & $1991-95$ & whole sample period \\
\hline city banks & 38.55 & 48.33 & 52.17 & 44.20 \\
$\begin{array}{c}\text { long-term } \\
\text { credit banks }\end{array}$ & 27.97 & 34.57 & 38.40 & 32.11 \\
trust banks & 31.30 & 43.39 & 43.74 & 37.12 \\
regional banks & 77.97 & 82.26 & 80.49 & 79.54 \\
total & 72.55 & 77.57 & 76.31 & 74.60 \\
\hline
\end{tabular}

Notes: The figures are average values of the sample period shown.

Source: Nikkei NEEDS Company Data Base 
Table 3 Summary Statistics: Proportion of Bank Loans Secured by Real Estate

$(\%)$

\begin{tabular}{|c|ccc|c|}
\hline & $1977-86$ & $1987-90$ & $1991-95$ & whole sample period \\
\hline city banks & 17.33 & 19.79 & 21.94 & 19.06 \\
$\begin{array}{c}\text { long-term } \\
\text { credit banks }\end{array}$ & 36.68 & 23.03 & 27.31 & 31.34 \\
trust banks & 32.33 & 24.22 & 25.53 & 28.83 \\
regional banks & 37.94 & 38.97 & 39.42 & 38.55 \\
total & 36.59 & 36.91 & 37.58 & 36.92 \\
\hline
\end{tabular}

Notes: The figures are average values of the sample period shown.

Source: Nikkei NEEDS Company Data Base

Table 4 Summary Statistics: Growth Rate of Bank Loans by Industries

(\%)

\begin{tabular}{|c|ccc|c|}
\hline & $1977-86$ & $1987-90$ & $1992-95$ & $\begin{array}{c}\text { whole sample period } \\
\text { excluding 1991 }\end{array}$ \\
\hline manufacturing & 5.29 & 1.333 & 1.147 & 3.39 \\
$\begin{array}{c}\text { construction } \\
\text { retail trade }\end{array}$ & 11.01 & 6.51 & 7.30 & 9.09 \\
$\begin{array}{c}\text { financial } \\
\text { institutions }\end{array}$ & 12.36 & 3.11 & 0.64 & 7.46 \\
$\begin{array}{c}\text { real estate } \\
\text { service }\end{array}$ & 13.55 & 25.03 & -0.74 & 21.96 \\
$\begin{array}{c}\text { personal and } \\
\text { others }\end{array}$ & 14.99 & 17.61 & 5.40 & 12.45 \\
$\begin{array}{c}\text { personal excluding } \\
\text { housing loans }\end{array}$ & 17.21 & 13.75 & 5.22 & 12.42 \\
\hline
\end{tabular}

Notes: The figures are average values of the sample period shown.

Source: Nikkei NEEDS Company Data Base 
Table 5

Descriptive Statistics of Fixed Investment Rate by Firm Size

$(\%)$

\begin{tabular}{|c|c|c|c|c|}
\hline $\begin{array}{c}\text { Firm size in terms } \\
\text { of capital } \\
\text { (million yen) }\end{array}$ & $75: 2-86: 4$ & $87: 1-91: 1$ & $91: 2-98: 1$ & $75: 2-98: 1$ \\
\hline \multicolumn{5}{|l|}{$\begin{array}{l}\text { Manufacturing } \\
\text { Industries }\end{array}$} \\
\hline $10-100$ & 4.10 & 4.47 & 2.69 & $\begin{array}{c}3.74 \\
(0.98)\end{array}$ \\
\hline $100-1000$ & 3.72 & 4.03 & 2.69 & $\begin{array}{r}3.47 \\
(0.74)\end{array}$ \\
\hline $1000-$ & 3.58 & 3.90 & 3.00 & $\begin{array}{r}3.46 \\
(0.63)\end{array}$ \\
\hline \multicolumn{5}{|l|}{$\begin{array}{l}\text { Non-manufacturing } \\
\text { Industries }\end{array}$} \\
\hline $10-100$ & 4.19 & 5.40 & 3.19 & $\begin{array}{c}4.11 \\
(0.99)\end{array}$ \\
\hline $100-1000$ & 4.24 & 4.38 & 3.29 & $\begin{array}{c}3.98 \\
(0.69)\end{array}$ \\
\hline $1000-$ & 4.02 & 4.78 & 3.77 & $\begin{array}{c}4.09 \\
(0.58)\end{array}$ \\
\hline
\end{tabular}

Notes: The values in parentheses are standard deviation.

Source: Quarterly Report of Financial Statements of Incorporated Business

Table 6 Summary Statistics: Growth Rate of Deposit

$(\%)$

\begin{tabular}{|c|ccc|c|}
\hline & $1977-86$ & $1987-90$ & $1991-95$ & whole sample period \\
\hline city banks & 11.46 & 16.22 & -3.12 & 8.62 \\
$\begin{array}{c}\text { long-term } \\
\text { credit banks }\end{array}$ & 14.93 & 16.34 & -5.85 & 9.76 \\
trust banks & 16.32 & 20.32 & -11.18 & 9.92 \\
regional banks & 9.96 & 11.13 & 3.02 & 8.38 \\
total & 10.46 & 11.96 & 1.80 & 8.50 \\
\hline
\end{tabular}

Notes: The figures are average values of the sample period shown.

Source: Nikkei NEEDS Company Data Base 
Table 7

Comparison of Selective Balance Sheet Items between Major Banks and Regional Banks:

- Sample Mean for the Period of 1976 to 1995 Based on Our Panel Data Set -

\begin{tabular}{|l|cc|}
\hline & Regional banks & Major banks \\
\hline total assets* & 1285.1 & 16091.6 \\
stock of call loan* & 45.0 & 366.0 \\
$\begin{array}{l}\text { stock of call money } \\
\text { borrowing* }\end{array}$ & 20.3 & 951.9 \\
$\begin{array}{l}\text { share of loans in } \\
\text { total assets** } \\
\begin{array}{l}\text { share of securities in } \\
\text { total assets** } \\
\text { share of time deposits } \\
\text { in total liabilities** }\end{array} \\
\begin{array}{l}\text { share of CD in total } \\
\text { liabilities** }\end{array}\end{array} \quad 66.4$ & 17.8 \\
\hline
\end{tabular}

Notes: Unit is billion yen for the items with * and percent for the items with **.

Source: Nikkei NEEDS Company Data Base 
Table 8-1

Estimation of the Euler Equation (4): Total Loans

(Major Banks)

\begin{tabular}{|c|c|c|c|c|c|c|}
\hline & $\begin{array}{l}\text { Reciprocal } \\
\text { of gross } \\
\text { discount } \\
\text { rate }\end{array}$ & $\begin{array}{l}\text { Interest } \\
\text { differential } \\
\text { (bank loan } \\
\text { - call rate) }\end{array}$ & $\begin{array}{l}\text { Gross rate } \\
\text { of change } \\
\text { in land }\end{array}$ & $\begin{array}{l}\text { Growth } \\
\text { rate of } \\
\text { deposits }\end{array}$ & $\begin{array}{c}\text { J-statistics } \\
\text { p-value }\end{array}$ & $\begin{array}{l}\text { Number of } \\
\text { observations }\end{array}$ \\
\hline 1981-94 & $\begin{array}{l}-3.2064 * * * \\
(-2.65) \\
-2.1452 \\
(-0.99) \\
0.0365 \\
(0.02)\end{array}$ & $\begin{array}{l}2.3144 \\
(1.44) \\
2.6070 * * \\
(2.29) \\
-2.9085 \\
(-1.38)\end{array}$ & $\begin{array}{l}-0.6182^{* *} \\
(-2.21) \\
\\
-1.1958^{* * *} \\
(-3.19)\end{array}$ & $\begin{array}{l}0.4207^{* * *} \\
(4.15) \\
0.5558^{* * *} \\
(5.46)\end{array}$ & $\begin{array}{c}28.3716 \\
0.000 \\
27.8479 \\
0.000 \\
11.2832 \\
0.080\end{array}$ & $\begin{array}{l}238 \\
238 \\
238\end{array}$ \\
\hline $1981-86$ & $\begin{array}{l}-8.1256^{* * *} \\
(-4.26) \\
-4.8894 * * \\
(-2.50) \\
-4.3535^{* *} \\
(-2.53)\end{array}$ & $\begin{array}{l}5.5050^{* * *} \\
(8.18) \\
3.0331 * * * \\
(3.78) \\
3.6523 * * * \\
(4.82)\end{array}$ & $\begin{array}{l}0.7093^{* * *} \\
(3.00) \\
0.9381^{* * *} \\
(3.75)\end{array}$ & $\begin{array}{l}0.3215^{* * *} \\
(5.20) \\
0.3306^{* * *} \\
(6.11)\end{array}$ & $\begin{array}{c}17.2155 \\
0.004 \\
6.0052 \\
0.306 \\
9.8755 \\
0.130\end{array}$ & $\begin{array}{l}102 \\
102 \\
102\end{array}$ \\
\hline $1987-90$ & $\begin{array}{l}7.5419 \\
(1.16) \\
-7.1335 \\
(-1.42) \\
4.4940 \\
(0.82)\end{array}$ & $\begin{array}{c}-20.3551^{* * *} \\
(-2.86) \\
2.4727 \\
(0.50) \\
-12.8865^{* *} \\
(-2.09)\end{array}$ & $\begin{array}{l}2.2145^{* * *} \\
(5.64) \\
\\
1.2410^{* * *} \\
(3.47)\end{array}$ & $\begin{array}{l}0.6583^{* * *} \\
(4.94) \\
0.4106^{* * *} \\
(2.97)\end{array}$ & $\begin{array}{l}2.4708 \\
0.781 \\
6.9249 \\
0.226 \\
4.2212 \\
0.647\end{array}$ & $\begin{array}{l}68 \\
68\end{array}$ \\
\hline 1991-94 & $\begin{array}{l}-2.5150 \\
(-1.54) \\
-1.9849 * * \\
(-2.28) \\
-3.7212 * * \\
(-2.43)\end{array}$ & $\begin{array}{l}6.8559^{* *} \\
(2.10) \\
4.6974^{* * *} \\
(2.71) \\
6.8685^{* * *} \\
(2.70)\end{array}$ & $\begin{array}{r}-0.1128 \\
(-1.00)\end{array}$ & $\begin{array}{l}0.1367^{* *} \\
(2.31) \\
0.2030^{* *} \\
(2.38)\end{array}$ & $\begin{array}{l}10.5602 \\
0.061 \\
8.4688 \\
0.132 \\
7.7422 \\
0.258\end{array}$ & $\begin{array}{l}68 \\
68 \\
68 \\
68\end{array}$ \\
\hline
\end{tabular}

Notes: The values in parentheses are t-values.

*** significant at the $1 \%$ level, ** significant at the $5 \%$ level. $\quad *$ significant at the $10 \%$ level 
Table 8-2

Estimation of the Euler Equations (4): Total Loans

(Regional Banks)

\begin{tabular}{|c|c|c|c|c|c|c|}
\hline & $\begin{array}{l}\text { Reciprocal } \\
\text { of gross } \\
\text { discount } \\
\text { rate }\end{array}$ & $\begin{array}{l}\text { Interest } \\
\text { differential } \\
\text { (bank loan } \\
\text { - call rate) }\end{array}$ & $\begin{array}{l}\text { Gross rate } \\
\text { al of change } \\
\text { in land }\end{array}$ & $\begin{array}{l}\text { Growth } \\
\text { rate of } \\
\text { deposits }\end{array}$ & $\begin{array}{c}\text { J-statistics } \\
\text { p-value }\end{array}$ & $\begin{array}{l}\text { Number of } \\
\text { observations }\end{array}$ \\
\hline 1981-94 & $\begin{array}{l}-1.9236^{* * *} \\
(-8.55) \\
-1.4792^{* * *} \\
(-5.66) \\
-1.4758^{* * *} \\
(-6.03)\end{array}$ & $\begin{array}{l}0.2752 \\
(1.04) \\
0.8653 * * * \\
(5.52) \\
0.3202 \\
(1.19)\end{array}$ & $\begin{array}{c}-0.2533 * * * \\
(-3.34) \\
* \\
-0.1933^{* * *} \\
(-2.69)\end{array}$ & $\begin{array}{l}0.1656 \\
(1.39) \\
0.2469^{* *} \\
(2.42)\end{array}$ & $\begin{array}{c}35.9887 \\
0.000 \\
66.2134 \\
0.000 \\
57.7906 \\
0.000\end{array}$ & $\begin{array}{l}1708 \\
1708 \\
1708\end{array}$ \\
\hline $1981-86$ & $\begin{array}{l}-1.2868^{* * *} \\
(-4.69) \\
-1.0934^{*} \\
(-1.92) \\
2.5176^{* * *} \\
(3.31)\end{array}$ & $\begin{array}{l}1.2097^{* * *} \\
(9.68) \\
0.6962^{* *} \\
(2.31) \\
-1.9024 * * * \\
(-3.73)\end{array}$ & $\begin{array}{l}* 0.0690 \\
(-0.73) \\
\\
\\
*-1.2432 * * * \\
(-4.90)\end{array}$ & $\begin{array}{l}0.4214 * * \\
(2.42) \\
1.6914 * * * \\
(6.73)\end{array}$ & $\begin{array}{c}61.5576 \\
0.000 \\
50.6181 \\
0.000 \\
2.4046 \\
0.879\end{array}$ & $\begin{array}{r}732 \\
732 \\
732\end{array}$ \\
\hline $1987-90$ & $\begin{array}{l}-1.1620 \\
(-0.57) \\
-19.7876^{* * *} \\
(-6.03) \\
-7.9713^{* * *} \\
(-3.05)\end{array}$ & $\begin{array}{l}-1.7456 \\
(-1.03) \\
* 13.4483^{* * *} \\
(5.34) \\
3.7159^{*} \\
(1.77)\end{array}$ & $\begin{array}{l}0.5704^{* * *} \\
(10.74) \\
* \begin{array}{l}0.4192^{* * * *} \\
(6.67)\end{array}\end{array}$ & $\begin{array}{l}0.9624 * * * \\
(7.58) \\
0.4169^{* * *} \\
(3.70)\end{array}$ & $\begin{array}{c}11.1374 \\
0.049 \\
22.1158 \\
0.000 \\
1.7880 \\
0.938\end{array}$ & $\begin{array}{r}488 \\
488 \\
488\end{array}$ \\
\hline 1991-94 & $\begin{array}{l}-3.9890^{* * *} \\
(-6.81) \\
-2.9222^{* * *} \\
(-5.19) \\
-3.6398^{* * *} \\
(-6.34)\end{array}$ & $\begin{array}{l}5.7609^{* * *} \\
(6.50) \\
3.8038^{* * *} \\
(4.59) \\
5.1065^{* * *} \\
(5.85)\end{array}$ & $\begin{array}{ll}* & 0.2687^{* * *} \\
& (8.28) \\
* & \\
* & 0.1087^{* *} \\
& (2.56)\end{array}$ & $\begin{array}{l}0.5671^{* * *} \\
(10.42) \\
0.4199^{* * *} \\
(5.43)\end{array}$ & $\begin{array}{c}19.5619 \\
0.002 \\
13.8737 \\
0.016 \\
12.0190 \\
0.062\end{array}$ & $\begin{array}{l}488 \\
488 \\
488\end{array}$ \\
\hline
\end{tabular}

Notes: See the notes in Table 7-1 
Table 9

Estimation of the Euler Equation (3): Loans by Firm Size

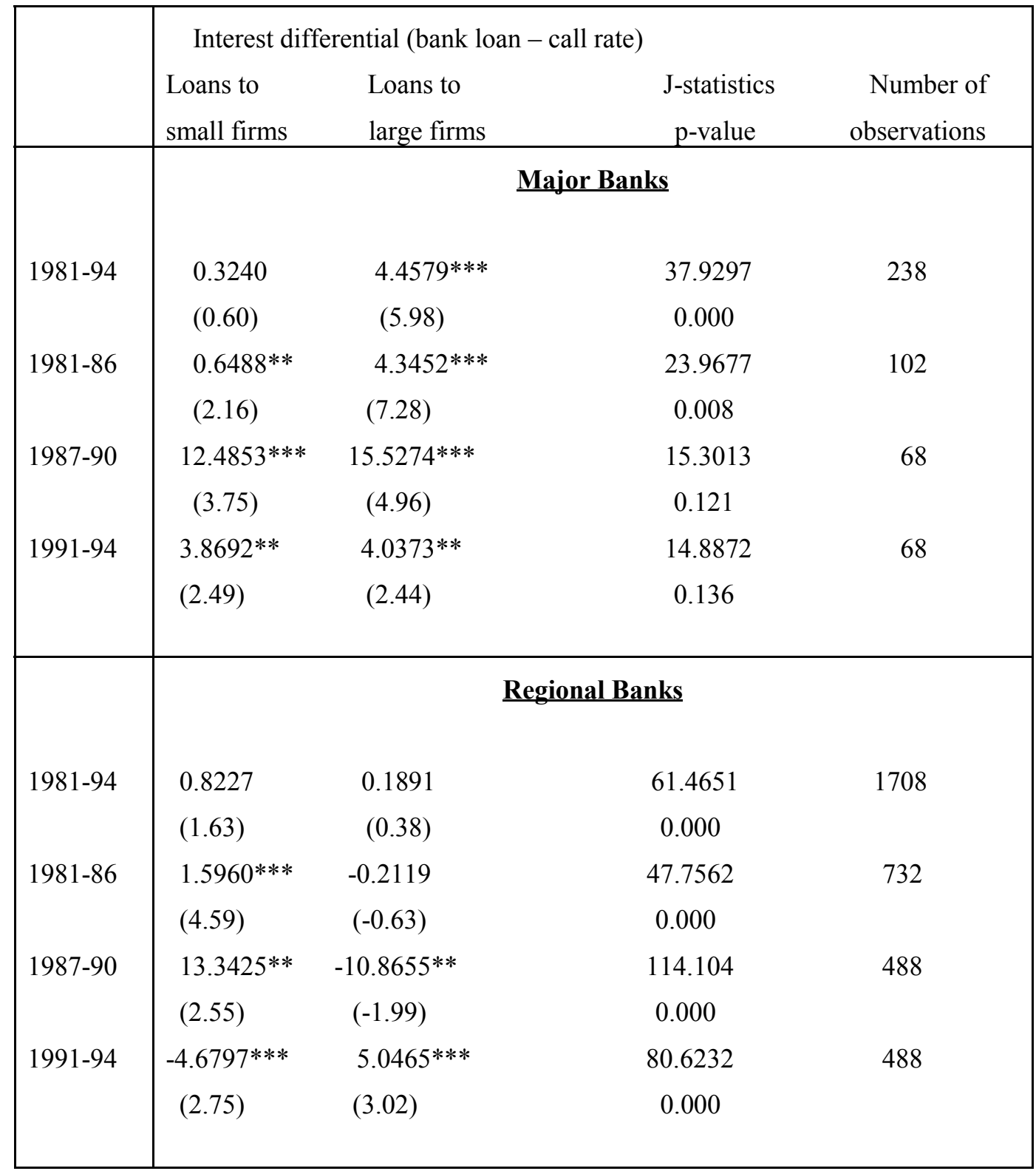

Notes: See the notes in Table 7-1 
Table 10-1

Estimation of the Euler Equations (4): Major Banks

Joint Estimation of Bank Loan Equation by Firm Size

\begin{tabular}{|c|c|c|c|c|c|c|}
\hline $\begin{array}{l}\text { Firm } \\
\text { Size }\end{array}$ & $\begin{array}{l}\text { Reciprocal } \\
\text { of gross } \\
\text { discount } \\
\text { rate }\end{array}$ & $\begin{array}{l}\text { Interest } \\
\text { differential } \\
\text { (bank loan } \\
\text { - call rate) }\end{array}$ & $\begin{array}{l}\text { Gross rate } \\
\text { of change } \\
\text { in land }\end{array}$ & $\begin{array}{l}\text { Growth } \\
\text { rate of } \\
\text { deposits }\end{array}$ & $\begin{array}{c}\text { J-statistics } \\
\text { p-value }\end{array}$ & $\begin{array}{c}\text { Number of } \\
\text { observations }\end{array}$ \\
\hline & \multicolumn{6}{|c|}{$\underline{1981-94}$} \\
\hline Small & $\begin{array}{l}0.3125 \\
(0.40)\end{array}$ & $\begin{array}{l}0.0958 \\
(0.12)\end{array}$ & $\begin{array}{r}-0.0212 \\
(-0.13)\end{array}$ & & 32.1447 & \\
\hline Large & $\begin{array}{l}-3.1518^{* * *} \\
(-3.82)\end{array}$ & $\begin{array}{l}2.7279 * * \\
(2.36)\end{array}$ & $\begin{array}{l}-0.5375^{* *} \\
(-2.47)\end{array}$ & & 0.004 & 238 \\
\hline Small & $\begin{array}{l}-0.5607 \\
(-0.40)\end{array}$ & $\begin{array}{l}0.5149 \\
(0.90)\end{array}$ & & $\begin{array}{r}0.0046 \\
(0.07)\end{array}$ & 36.4250 & \\
\hline Large & $\begin{array}{l}-2.0695 \\
(-1.41)\end{array}$ & $\begin{array}{l}2.5772 * * * \\
(3.06)\end{array}$ & & $\begin{array}{l}0.3463^{* * *} \\
(4.68)\end{array}$ & 0.000 & 238 \\
\hline Small & $\begin{array}{l}0.5468 \\
(0.69)\end{array}$ & $\begin{array}{l}-0.5202 \\
(-0.64)\end{array}$ & $\begin{array}{r}-0.0824 \\
(-0.51)\end{array}$ & $\begin{array}{c}0.0949^{* *} \\
(1.96)\end{array}$ & 32.1447 & \\
\hline \multirow[t]{2}{*}{ Large } & $\begin{array}{l}-1.2688 \\
(-1.26)\end{array}$ & $\begin{array}{l}-0.3455 \\
(-0.26)\end{array}$ & $\begin{array}{l}-0.6999 * * * \\
(-3.02)\end{array}$ & $\begin{array}{c}0.3928^{* * * *} \\
(5.56)\end{array}$ & 0.004 & 238 \\
\hline & \multicolumn{6}{|c|}{$1981-86$} \\
\hline Small & $\begin{array}{l}-2.9410 * * * \\
(-2.80)\end{array}$ & $\begin{array}{l}0.9674 * * * \\
(3.14)\end{array}$ & $\begin{array}{l}0.4047 * * * \\
(2.57)\end{array}$ & & 25.2249 & \\
\hline Large & $\begin{array}{l}-4.8787 * * * \\
(-3.07)\end{array}$ & $\begin{array}{l}4.5941^{* * *} \\
(8.28)\end{array}$ & $\begin{array}{l}0.2395 \\
(1.07)\end{array}$ & & 0.014 & 102 \\
\hline Small & $\begin{array}{l}-3.2753^{* * *} \\
(-2.68)\end{array}$ & $\begin{array}{l}0.9889^{* * *} \\
(2.88)\end{array}$ & & $\begin{array}{c}-0.0739 * * \\
(-2.13)\end{array}$ & 22.6166 & \\
\hline Large & $\begin{array}{l}1.7421 \\
(1.19)\end{array}$ & $\begin{array}{l}1.7188^{* * *} \\
(2.65)\end{array}$ & & $\begin{array}{l}0.3867^{* * *} \\
(8.29)\end{array}$ & 0.031 & 102 \\
\hline Small & $\begin{array}{l}-2.1958^{* *} \\
(-2.11)\end{array}$ & $\begin{array}{l}1.0036^{* * *} \\
(3.29)\end{array}$ & $\begin{array}{r}0.2259 \\
(1.49)\end{array}$ & $\begin{array}{r}-0.0476 \\
(-1.55)\end{array}$ & 22.5830 & \\
\hline Large & $\begin{array}{l}-0.3198 \\
(-0.20)\end{array}$ & $\begin{array}{l}2.2340 * * * \\
(3.40)\end{array}$ & $\begin{array}{l}0.5156^{* * *} \\
(2.72)\end{array}$ & $\begin{array}{l}0.3839 * * * \\
(8.41)\end{array}$ & 0.067 & 102 \\
\hline
\end{tabular}


Table 10-1 (continued)

Estimation of the Euler Equations (4): Major Banks

Joint Estimation of Bank Loan Equation by Firm Size

\begin{tabular}{|c|c|c|c|c|c|c|}
\hline $\begin{array}{l}\text { Firm } \\
\text { Size }\end{array}$ & $\begin{array}{l}\text { Reciprocal } \\
\text { of gross } \\
\text { discount } \\
\quad \text { rate }\end{array}$ & $\begin{array}{c}\text { Interest } \\
\text { differential } \\
\text { (bank loan } \\
\text { - call rate) }\end{array}$ & $\begin{array}{l}\text { Gross rate } \\
\text { of change } \\
\text { in land }\end{array}$ & $\begin{array}{l}\text { Growth } \\
\text { rate of } \\
\text { deposits }\end{array}$ & $\begin{array}{c}\text { J-statistics } \\
\text { p-value }\end{array}$ & $\begin{array}{r}\text { Number of } \\
\text { observations }\end{array}$ \\
\hline & \multicolumn{6}{|c|}{$1987-90$} \\
\hline Small & $\begin{array}{l}6.3814^{*} \\
(1.67)\end{array}$ & $\begin{array}{l}-11.3010^{* * *} \\
(-2.76)\end{array}$ & $\begin{array}{l}{ }^{*} 1.0363^{* * *} \\
(4.69)\end{array}$ & & 8.9156 & \\
\hline Large & $\begin{array}{l}-6.8868^{*} \\
(-1.89)\end{array}$ & $\begin{array}{l}1.6724 \\
(0.42)\end{array}$ & $\begin{array}{l}0.4984^{* * *} \\
(2.78)\end{array}$ & & 0.710 & 68 \\
\hline Small & $\begin{array}{l}0.1813 \\
(0.07)\end{array}$ & $\begin{array}{c}-0.7349 \\
(-0.30)\end{array}$ & & $\begin{array}{l}0.2938^{* * *} \\
(4.83)\end{array}$ & 11.5878 & \\
\hline Large & $\begin{array}{l}-8.7740 * * \\
(-2.32)\end{array}$ & $\begin{array}{l}4.7829 \\
(1.37)\end{array}$ & & $\begin{array}{l}0.3377^{* * *} \\
(3.87)\end{array}$ & 0.479 & 68 \\
\hline Small & $\begin{array}{l}9.2806^{* *} \\
(2.51)\end{array}$ & $\begin{array}{l}-12.6014^{* * *} \\
(-3.04)\end{array}$ & $\begin{array}{c}* 0.8338^{* * *} \\
(3.06)\end{array}$ & $\begin{array}{c}0.1631^{*} \\
(1.81)\end{array}$ & 11.9630 & \\
\hline \multirow[t]{2}{*}{ Large } & $\begin{array}{l}-4.0512 \\
(-0.89)\end{array}$ & $\begin{array}{l}-0.2732 \\
(-0.05)\end{array}$ & $\begin{array}{l}0.1878 \\
(0.66)\end{array}$ & $\begin{array}{c}0.2944^{* * *} \\
(2.82)\end{array}$ & 0.609 & 68 \\
\hline & \multicolumn{6}{|c|}{ 1991-94 } \\
\hline Small & $\begin{array}{l}0.5102 \\
(0.43)\end{array}$ & $\begin{array}{l}1.1226 \\
(0.53)\end{array}$ & $\begin{array}{l}0.0885 \\
(1.52)\end{array}$ & & 15.3971 & \\
\hline Large & $\begin{array}{l}-4.0082 * * * \\
(-3.84)\end{array}$ & $\begin{array}{l}6.2466^{* * *} \\
(3.30)\end{array}$ & $\begin{array}{l}-0.0517 \\
(-1.06)\end{array}$ & & 0.220 & 68 \\
\hline Small & $\begin{array}{l}-0.4245 \\
(-0.43)\end{array}$ & $\begin{array}{c}2.3328 \\
(1.46)\end{array}$ & & $\begin{array}{l}0.0624 \\
(1.44)\end{array}$ & 14.0234 & \\
\hline Large & $\begin{array}{l}-2.1624 * * \\
(-2.12)\end{array}$ & $\begin{array}{l}3.5157^{* *} \\
(2.17)\end{array}$ & & $\begin{array}{l}0.0466 \\
(1.21)\end{array}$ & 0.299 & 68 \\
\hline Small & $\begin{array}{l}-0.1527 \\
(-0.11)\end{array}$ & $\begin{array}{l}1.6229 \\
(0.79)\end{array}$ & $\begin{array}{r}0.0401 \\
(0.47)\end{array}$ & $\begin{array}{l}0.0393 \\
(0.58)\end{array}$ & 13.6869 & \\
\hline Large & $\begin{array}{l}-5.0037 * * * \\
(-3.27)\end{array}$ & $\begin{array}{l}6.8697^{* * *} \\
(3.16)\end{array}$ & $\begin{array}{c}-0.1995 * * \\
(-2.00)\end{array}$ & $\begin{array}{c}0.1445^{*} \\
(1.73)\end{array}$ & 0.473 & 68 \\
\hline
\end{tabular}

Notes: See the notes in Table 7-1 
Table 10-2

Estimation of the Euler Equations (4): Regional Banks

Joint Estimation of Bank Loan Equation by Firm Size

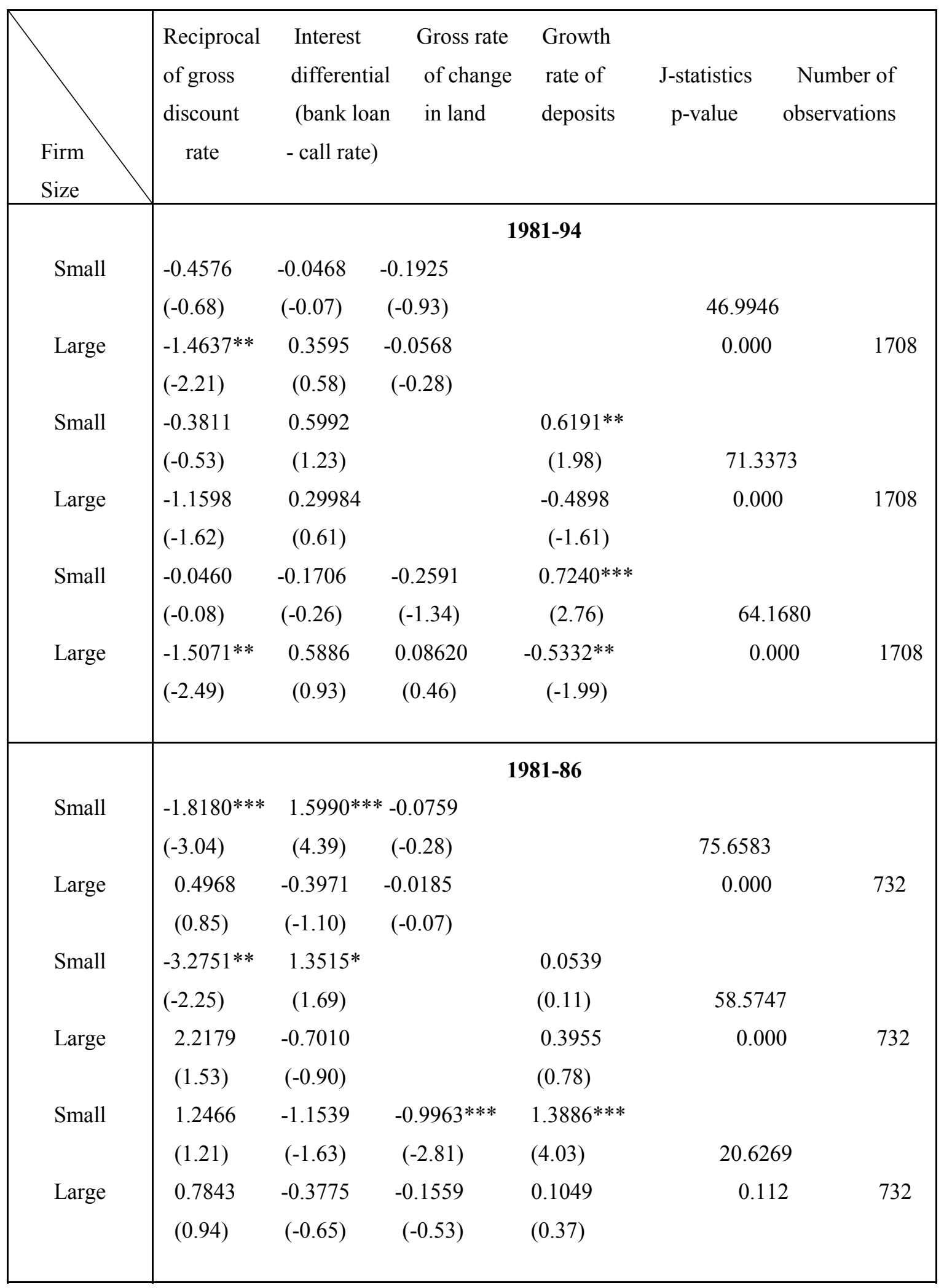


Table 10-2 (continued)

Estimation of the Euler Equations (4): Regional Banks

Joint Estimation of Bank Loan Equation by Firm Size

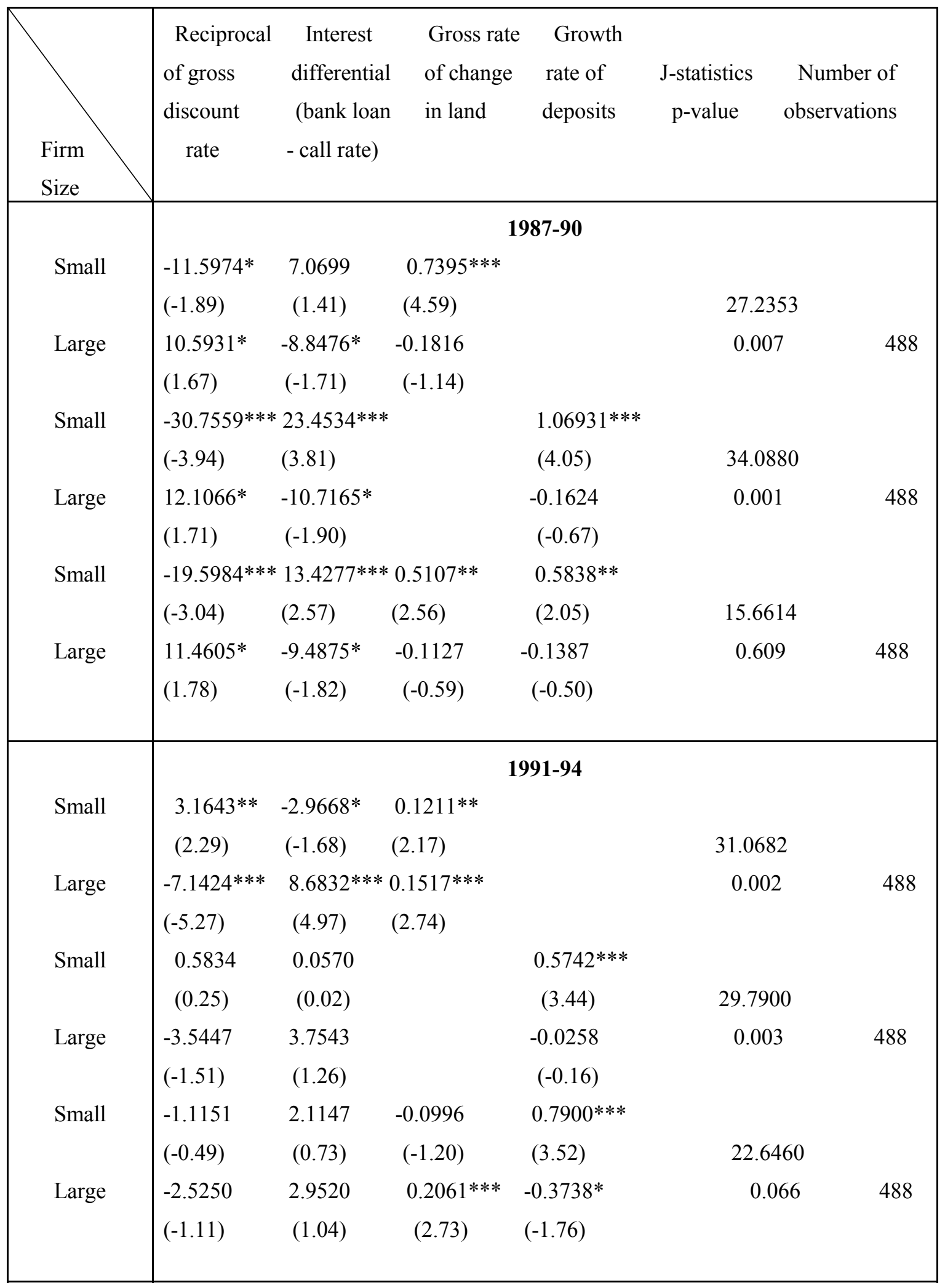

Notes: See the notes in Table 7-1. 
Table 11-1

Estimation of the Euler Equations (4): Major Banks

Joint Estimation of Bank Loan Equation by Industries

\begin{tabular}{|c|c|c|c|c|c|c|}
\hline Industry & $\begin{array}{l}\text { Reciprocal } \\
\text { of gross } \\
\text { discount } \\
\quad \text { rate }\end{array}$ & $\begin{array}{c}\text { Interest } \\
\text { differential } \\
\text { (bank loan } \\
\text { - call rate) }\end{array}$ & $\begin{array}{l}\text { Gross rate } \\
\text { of change } \\
\text { in land }\end{array}$ & $\begin{array}{l}\text { Growth } \\
\text { rate of } \\
\text { deposits }\end{array}$ & $\begin{array}{c}\text { J-statistics } \\
\text { p-value }\end{array}$ & $\begin{array}{l}\text { Number of } \\
\text { observations }\end{array}$ \\
\hline & \multicolumn{6}{|c|}{ 1981-94 } \\
\hline M & $\begin{array}{l}-0.5707 * * * \\
(-2.85)\end{array}$ & $\begin{array}{c}0.5684^{*} \\
(1.78)\end{array}$ & $\begin{array}{r}0.0414 \\
(0.70)\end{array}$ & & 49.0203 & \\
\hline NM & $\begin{array}{l}-0.5745 \\
(-0.48)\end{array}$ & $\begin{array}{l}-0.9092 \\
(-0.51)\end{array}$ & $\begin{array}{l}-0.9596 * * * \\
(-3.17)\end{array}$ & & 0.000 & 238 \\
\hline M & $\begin{array}{l}1.1145^{* *} \\
(2.08)\end{array}$ & $\begin{array}{l}-0.1919 \\
(-0.76)\end{array}$ & & $\begin{array}{l}0.0752 * * \\
(2.27)\end{array}$ & 38.5774 & \\
\hline NM & $\begin{array}{l}-3.4985^{*} \\
(-1.88)\end{array}$ & $\begin{array}{l}2.9634^{* * * *} \\
(2.96)\end{array}$ & & $\begin{array}{l}0.2967 * * * \\
(3.16)\end{array}$ & 0.000 & 238 \\
\hline M & $\begin{array}{l}-0.4663^{* *} \\
(-2.21)\end{array}$ & $\begin{array}{l}0.5534^{*} \\
(1.83)\end{array}$ & $\begin{array}{l}0.0370 \\
(0.65)\end{array}$ & $\begin{array}{l}-0.0078 \\
(-0.48)\end{array}$ & 38.1193 & \\
\hline \multirow[t]{2}{*}{ NM } & $\begin{array}{l}2.0796 \\
(1.31)\end{array}$ & $\begin{array}{l}-4.1086^{* *} \\
(-2.20)\end{array}$ & $\begin{array}{l}-1.2936^{* * *} \\
(-3.70)\end{array}$ & $\begin{array}{c}0.5664^{* * *} \\
(6.16)\end{array}$ & 0.000 & 238 \\
\hline & \multicolumn{6}{|c|}{ 1981-86 } \\
\hline M & $\begin{array}{l}-0.3461 \\
(-0.86)\end{array}$ & $\begin{array}{l}-0.1155 \\
(-0.79)\end{array}$ & $\begin{array}{l}0.0082 \\
(0.10)\end{array}$ & & 34.6627 & \\
\hline NM & $\begin{array}{l}-6.8660 * * * \\
(-3.07)\end{array}$ & $\begin{array}{l}4.8061^{* * *} \\
(8.28)\end{array}$ & $\begin{array}{l}0.5213^{* *} \\
(1.07)\end{array}$ & & 0.001 & 102 \\
\hline M & $\begin{array}{l}0.9152 \\
(1.43)\end{array}$ & $\begin{array}{l}-0.3361^{*} \\
(-1.81)\end{array}$ & & $\begin{array}{r}0.0191 \\
(1.03)\end{array}$ & 24.9661 & \\
\hline NM & $\begin{array}{l}-4.7393^{* *} \\
(-2.49)\end{array}$ & $\begin{array}{l}2.4112^{* * *} \\
(3.91)\end{array}$ & & $\begin{array}{l}0.2785^{* * *} \\
(4.36)\end{array}$ & 0.015 & 102 \\
\hline M & $\begin{array}{l}-0.6441 \\
(-1.39)\end{array}$ & $\begin{array}{l}-0.1424 \\
(-0.80)\end{array}$ & $\begin{array}{r}0.0582 \\
(0.76)\end{array}$ & $\begin{array}{l}0.0025 \\
(0.15)\end{array}$ & 28.1423 & \\
\hline NM & $\begin{array}{l}-1.6035 \\
(-0.97)\end{array}$ & $\begin{array}{l}2.4055^{* * *} \\
(4.09)\end{array}$ & $\begin{array}{c}0.5887^{* *} \\
(2.42)\end{array}$ & $\begin{array}{l}0.3716^{* * *} \\
(7.56)\end{array}$ & 0.014 & 102 \\
\hline
\end{tabular}


Table 11-1 (continued)

Estimation of the Euler Equations (4): Major Banks

Joint Estimation of Bank Loan Equation by Industries

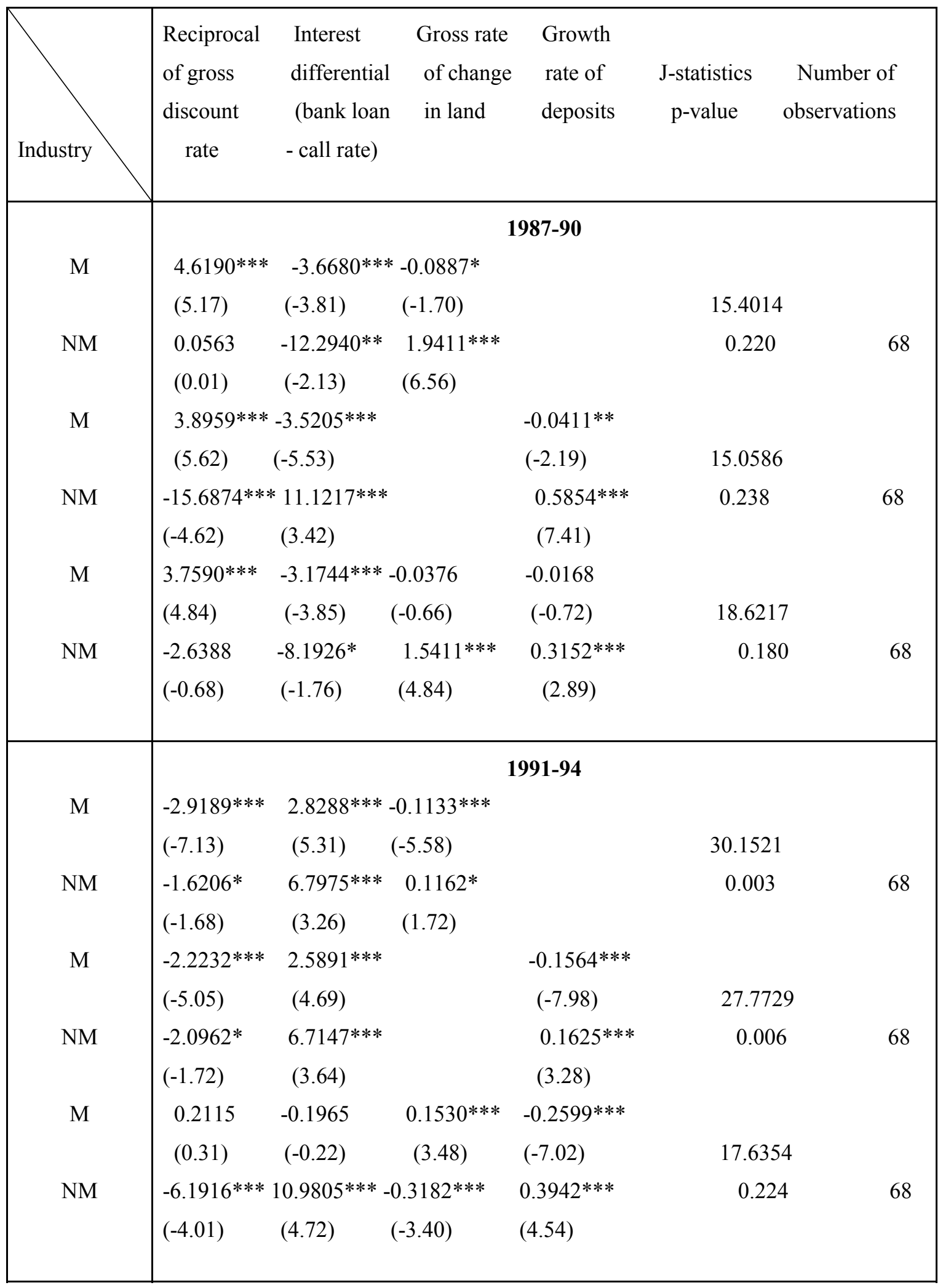

Notes: M stands for manufacturing industries and NM stands for non-manufacturing industries.

See also the notes in Table 7-1. 
Table 11-2

Estimation of the Euler Equations (4): Regional Banks

Joint Estimation of Bank Loan Equation by Industries

\begin{tabular}{|c|c|c|c|c|c|c|}
\hline \multirow{2}{*}{ Industry } & \multirow{2}{*}{$\begin{array}{l}\text { Reciprocal } \\
\text { of gross } \\
\text { discount } \\
\text { rate }\end{array}$} & $\begin{array}{l}\text { Interest } \\
\text { differential } \\
\text { (bank loan } \\
\text { - call rate) }\end{array}$ & $\begin{array}{l}\text { Gross rate } \\
\text { of change } \\
\text { in land }\end{array}$ & $\begin{array}{l}\text { Growth } \\
\text { rate of } \\
\text { deposits }\end{array}$ & \multirow[t]{2}{*}{$\begin{array}{c}\text { J-statistics } \\
\text { p-value }\end{array}$} & $\begin{array}{l}\text { Number of } \\
\text { observations }\end{array}$ \\
\hline & & & & 1981-94 & & \\
\hline M & $\begin{array}{l}-0.6621^{* * *} \\
(-9.48)\end{array}$ & $\begin{array}{l}0.5643^{* * *} \\
(7.35)\end{array}$ & $\begin{array}{c}* 0.1418^{* * *} \\
(7.36)\end{array}$ & & 140.203 & \\
\hline NM & $\begin{array}{l}-1.1342 * * * \\
(-5.65)\end{array}$ & $\begin{array}{c}0.1110 \\
(0.47)\end{array}$ & $\begin{array}{l}-0.3201 * * * \\
(-5.12)\end{array}$ & & 0.000 & 1708 \\
\hline M & $\begin{array}{l}-0.2863^{* *} \\
(-2.52)\end{array}$ & $\begin{array}{l}0.2357 * * * \\
(3.56)\end{array}$ & & $\begin{array}{c}0.1773^{* * *} \\
(3.48)\end{array}$ & 148.720 & \\
\hline NM & $\begin{array}{l}-1.2937^{* * *} \\
(-5.19)\end{array}$ & $\begin{array}{l}0.7739 * * * \\
(5.19)\end{array}$ & & $\begin{array}{r}-0.0011 \\
(-0.01)\end{array}$ & 0.000 & 1708 \\
\hline M & $\begin{array}{l}-1.0001^{* * *} \\
(-7.29)\end{array}$ & $\begin{array}{l}0.9257^{* * *} \\
(7.22)\end{array}$ & $\begin{array}{c}0.2208^{* * *} \\
(6.68)\end{array}$ & $\begin{array}{l}-0.2933^{* * *} \\
(-5.06)\end{array}$ & 92.9575 & \\
\hline NM & $\begin{array}{l}-0.3553 \\
(-1.37)\end{array}$ & $\begin{array}{c}-0.4488^{*} \\
(-1.74)\end{array}$ & $\begin{array}{l}-0.3636^{* * *} \\
(-5.46)\end{array}$ & $\begin{array}{l}0.5266^{* * *} \\
(5.10)\end{array}$ & 0.000 & 1708 \\
\hline & & & & 981-86 & & \\
\hline M & $\begin{array}{l}-0.3933^{* * *} \\
(-4.15)\end{array}$ & $\begin{array}{c}0.0614 \\
(1.43)\end{array}$ & $\begin{array}{l}-0.1177^{* * *} \\
(-3.58)\end{array}$ & & 101.803 & \\
\hline NM & $\begin{array}{l}-1.2500^{* * *} \\
(-5.63)\end{array}$ & $\begin{array}{l}1.2576^{* * *} \\
(12.11)\end{array}$ & $\begin{array}{l}0.0926 \\
(1.13)\end{array}$ & & 0.000 & 732 \\
\hline M & $\begin{array}{l}0.2379 \\
(0.92)\end{array}$ & $\begin{array}{l}-0.3809 * * * \\
(-2.69)\end{array}$ & & $\begin{array}{l}0.3318^{* * *} \\
(4.12)\end{array}$ & 81.1811 & \\
\hline NM & $\begin{array}{l}-0.9681^{* *} \\
(-2.35)\end{array}$ & $\begin{array}{l}0.6919^{* * *} \\
(3.14)\end{array}$ & & $\begin{array}{l}0.3952^{* * * *} \\
(3.12)\end{array}$ & 0.000 & 732 \\
\hline M & $\begin{array}{l}1.4890 * * * \\
(4.19)\end{array}$ & $\begin{array}{c}-1.3775^{* * *} \\
(-5.49)\end{array}$ & $\begin{array}{c}-0.6701 * * * \\
(-5.57)\end{array}$ & $\begin{array}{l}0.7407^{* * *} \\
(5.92)\end{array}$ & 35.5325 & \\
\hline NM & $\begin{array}{l}0.7456^{*} \\
(1.77)\end{array}$ & $\begin{array}{c}-0.4058 \\
(-1.44)\end{array}$ & $\begin{array}{l}-0.5774 * * * \\
(-4.00)\end{array}$ & $\begin{array}{l}0.8739 * * * \\
(6.18)\end{array}$ & 0.001 & 732 \\
\hline
\end{tabular}


Table 11-2 (continued)

Estimation of the Euler Equations (4): Regional Banks

Joint Estimation of Bank Loan Equation by Industries

\begin{tabular}{|c|c|c|c|c|c|c|}
\hline \multirow{2}{*}{ Industry } & $\begin{array}{l}\text { Reciprocal } \\
\text { of gross } \\
\text { discount } \\
\text { rate }\end{array}$ & $\begin{array}{c}\text { Interest } \\
\text { differential } \\
\text { (bank loan } \\
\text { - call rate) }\end{array}$ & $\begin{array}{l}\text { Gross rate } \\
\text { of change } \\
\text { in land }\end{array}$ & \multirow[t]{2}{*}{$\begin{array}{l}\text { Growth } \\
\text { rate of } \\
\text { deposits }\end{array}$} & \multirow[t]{2}{*}{$\begin{array}{c}\text { J-statistics } \\
\text { p-value }\end{array}$} & $\begin{array}{l}\text { Number of } \\
\text { observations }\end{array}$ \\
\hline & & & & & & \\
\hline M & $\begin{array}{l}-0.1959 \\
(-0.43)\end{array}$ & $\begin{array}{l}0.1454 \\
(0.39)\end{array}$ & $\begin{array}{l}-0.0568 * * * \\
(-4.02)\end{array}$ & & 33.7229 & \\
\hline NM & $\begin{array}{l}-1.5636 \\
(-0.83)\end{array}$ & $\begin{array}{r}-1.4316 \\
(-0.92)\end{array}$ & $\begin{array}{l}0.6465^{* * *} \\
(12.68)\end{array}$ & & 0.001 & 488 \\
\hline M & $\begin{array}{l}1.1584 \\
(1.53)\end{array}$ & $\begin{array}{l}-0.9640 \\
(-1.62)\end{array}$ & & $\begin{array}{l}-0.0912 * * * \\
(-3.12)\end{array}$ & 38.3718 & \\
\hline NM & $\begin{array}{l}-20.4249 * * * \\
(-5.97)\end{array}$ & $\begin{array}{l}* 14.0652 * * * \\
(5.31)\end{array}$ & & $\begin{array}{l}1.0481^{* * * *} \\
(8.12)\end{array}$ & 0.000 & 488 \\
\hline M & $\begin{array}{l}0.0971 \\
(0.14)\end{array}$ & $\begin{array}{l}-0.0631 \\
(-0.11)\end{array}$ & $\begin{array}{l}-0.0479 * * * \\
(-2.65)\end{array}$ & $\begin{array}{l}-0.0246 \\
(-0.74)\end{array}$ & 21.6257 & \\
\hline NM & $\begin{array}{l}-7.9932 * * * \\
(-3.46)\end{array}$ & $\begin{array}{l}3.7197^{* *} \\
(1.99)\end{array}$ & $\begin{array}{l}0.4797^{* * *} \\
(8.07)\end{array}$ & $\begin{array}{l}0.4508^{* * *} \\
(4.71)\end{array}$ & 0.087 & 488 \\
\hline & & & & 1991-94 & & \\
\hline M & $\begin{array}{l}-2.1169^{* * *} \\
(-9.19)\end{array}$ & $\begin{array}{l}2.4643^{* * * *} \\
(7.18)\end{array}$ & $\begin{array}{l}0.0631 * * * \\
(5.00)\end{array}$ & & 129.554 & \\
\hline NM & $\begin{array}{l}-1.8417^{* * *} \\
(-3.52)\end{array}$ & $\begin{array}{l}3.1875^{* * *} \\
(4.11)\end{array}$ & $\begin{array}{l}0.1850^{* * *} \\
(5.92)\end{array}$ & & 0.000 & 488 \\
\hline M & $\begin{array}{l}-0.5648 * * \\
(-2.48)\end{array}$ & $\begin{array}{l}0.2019 \\
(0.60)\end{array}$ & & $\begin{array}{l}-0.1451^{* * *} \\
(-5.75)\end{array}$ & 83.9530 & \\
\hline NM & $\begin{array}{l}-2.3032 * * * \\
(-4.30)\end{array}$ & $\begin{array}{l}3.5271 * * * \\
(4.36)\end{array}$ & & $\begin{array}{l}0.6930^{* * *} \\
(11.46)\end{array}$ & 0.000 & 488 \\
\hline M & $\begin{array}{l}-1.6332 * * * \\
(-4.49)\end{array}$ & $\begin{array}{l}1.9790 * * * \\
(3.58)\end{array}$ & $\begin{array}{l}0.1689 * * * \\
(6.42)\end{array}$ & $\begin{array}{l}-0.3727^{* * *} \\
(-6.96)\end{array}$ & 30.0948 & \\
\hline NM & $\begin{array}{l}-1.7380 * * * \\
(-2.94)\end{array}$ & $\begin{array}{l}2.9376^{* * *} \\
(3.28)\end{array}$ & $\begin{array}{l}-0.0426 \\
(-1.03)\end{array}$ & $\begin{array}{l}0.7474 * * * \\
(9.21)\end{array}$ & 0.007 & 488 \\
\hline
\end{tabular}

Notes: M stands for manufacturing industries and NM stands for non-manufacturing industries.

See also the notes in Table 7-1. 
Table 12

Effect of the Basle Accord on Bank's Lending Activity: 1992-1994

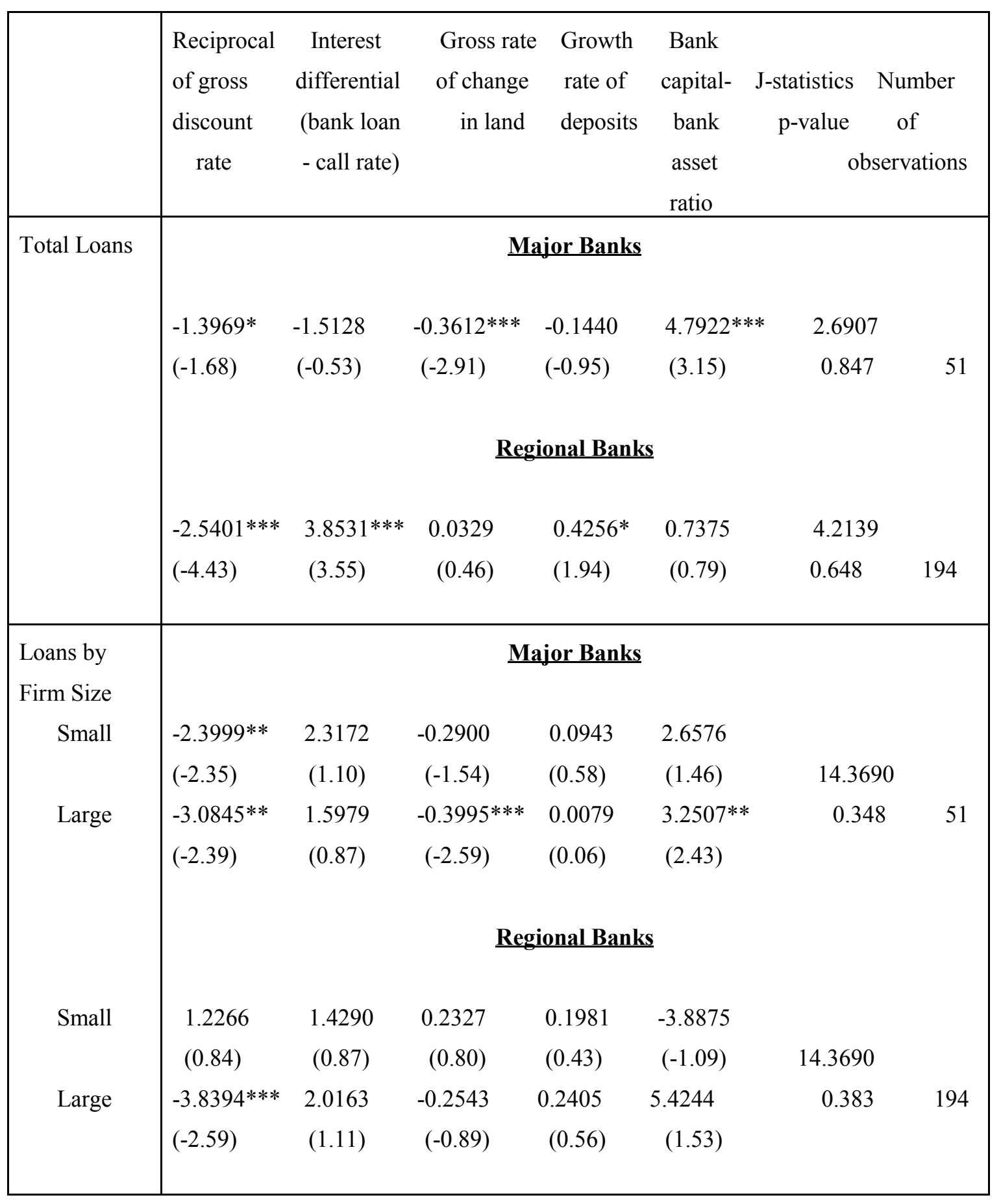


Table 12 (continued)

Effect of the Basle Accord on Bank's Lending Activity: 1992-1994

\begin{tabular}{|c|c|c|c|c|c|c|c|}
\hline & $\begin{array}{l}\text { Reciprocal } \\
\text { of gross } \\
\text { discount } \\
\text { rate }\end{array}$ & $\begin{array}{c}\text { Interest } \\
\text { differential } \\
\text { (bank loan } \\
\text { - call rate) }\end{array}$ & $\begin{array}{l}\text { Gross rate } \\
\text { of change } \\
\text { in land }\end{array}$ & $\begin{array}{l}\text { Growth } \\
\text { rate of } \\
\text { deposits }\end{array}$ & $\begin{array}{c}\text { Bank } \\
\text { capital- J-s } \\
\text { bank } \\
\text { asset } \\
\text { ratio } \\
\end{array}$ & $\begin{array}{l}\text { statistics } \mathrm{N} \\
\text { p-value } \\
\quad \text { obser }\end{array}$ & \\
\hline $\begin{array}{l}\text { Loans by } \\
\text { Industries }\end{array}$ & \multicolumn{7}{|c|}{ Major Banks } \\
\hline \multirow[b]{2}{*}{ NM } & $\begin{array}{l}-0.5242^{* *} \\
(-2.10)\end{array}$ & $\begin{array}{l}0.2471 \\
(0.64)\end{array}$ & $\begin{array}{c}0.0674^{* *} \\
(2.24)\end{array}$ & $\begin{array}{l}-0.0807^{* * *} \\
(-3.20)\end{array}$ & $\begin{array}{l}0.9312^{* * *} \\
(4.28)\end{array}$ & 12.2131 & \\
\hline & $\begin{array}{l}-2.2757 * * * \\
(-2.82)\end{array}$ & $\begin{array}{l}1.0478 \\
(0.50)\end{array}$ & $\begin{array}{l}-0.3899 * * \\
(-2.50) \\
\quad \underline{\mathbf{R e g}}\end{array}$ & $\begin{array}{l}-0.2329 \\
(-1.36) \\
\text { gional Banks }\end{array}$ & $\begin{array}{l}3.3251^{* *} \\
(2.09)\end{array}$ & 0.510 & 51 \\
\hline M & $\begin{array}{l}-1.2866^{* * *} \\
(-5.73)\end{array}$ & $\begin{array}{l}1.0236^{* * *} \\
(2.61)\end{array}$ & $\begin{array}{l}0.0792^{* * *} \\
(2.67)\end{array}$ & $\begin{array}{l}0.0104 \\
(0.13)\end{array}$ & $\begin{array}{l}1.6571^{* * *} \\
(4.33)\end{array}$ & 27.9712 & \\
\hline NM & $\begin{array}{l}-1.1281^{* *} \\
(-2.42)\end{array}$ & $\begin{array}{l}3.0322 * * * \\
(3.25)\end{array}$ & $\begin{array}{l}-0.0091 \\
(-0.15)\end{array}$ & $\begin{array}{l}0.3310^{*} \\
(1.89)\end{array}$ & $\begin{array}{l}-1.4824^{*} \\
(-1.86)\end{array}$ & 0.014 & 194 \\
\hline
\end{tabular}

Notes: M stands for manufacturing industries and NM stands for non-manufacturing industries.

See also the notes in Table 7-1. 
Table 13

Descriptive Statistics of Marginal q by Firm Size

\begin{tabular}{|c|c|c|c|c|}
\hline $\begin{array}{c}\text { Firm size in terms } \\
\text { of capital } \\
\text { (million yen) }\end{array}$ & $75: 4-86: 4$ & $87: 1-91: 1$ & $91: 2-98: 1$ & $75: 2-98: 1$ \\
\hline \multicolumn{5}{|l|}{$\begin{array}{l}\text { Manufacturing } \\
\text { Industries }\end{array}$} \\
\hline & 1.66 & 1.89 & 0.93 & $\begin{array}{r}1.47 \\
(0.47)\end{array}$ \\
\hline $100-1000$ & 1.10 & 1.06 & 0.64 & $\begin{array}{c}0.95 \\
(0.28)\end{array}$ \\
\hline $1000-$ & 0.96 & 1.04 & 0.75 & $\begin{array}{c}0.91 \\
(0.22)\end{array}$ \\
\hline \multicolumn{5}{|l|}{$\begin{array}{l}\text { Non-manufacturing } \\
\text { Industries }\end{array}$} \\
\hline & 1.54 & 1.91 & 1.16 & $\begin{array}{r}1.49 \\
(0.36)\end{array}$ \\
\hline $100-1000$ & 0.91 & 0.98 & 0.48 & $\begin{array}{r}0.79 \\
(0.27)\end{array}$ \\
\hline $1000-$ & 0.80 & 0.92 & 0.57 & $\begin{array}{c}0.75 \\
(0.17)\end{array}$ \\
\hline
\end{tabular}

Notes: The values in parentheses are standard deviation. 
Table 14

Estimation Results of Investment Function by Firm Size

\begin{tabular}{|c|c|c|c|}
\hline $\begin{array}{c}\text { Firm size in terms } \\
\text { of capital } \\
\text { (million yen) }\end{array}$ & $\begin{array}{l}\text { Marginal q } \\
\text { Equation.3 }\}\end{array}$ & $\begin{array}{l}\text { Growth rate } \\
\text { of loans }\end{array}$ & $\begin{array}{l}\{\text { EMBED } \\
\text { S.E. }\end{array}$ \\
\hline $\begin{array}{l}\text { Manufacturing } \\
\text { Industries } \\
10-100\end{array}$ & $\begin{array}{l}0.0092 * * * \\
(3.51)\end{array}$ & $\begin{array}{l}0.1675^{* *} \\
(2.44)\end{array}$ & $\begin{array}{l}0.9215 \\
0.0029\end{array}$ \\
\hline $100-1000$ & $\begin{array}{l}0.0050^{*} \\
(1.79)\end{array}$ & $\begin{array}{l}0.2534^{*} \\
(1.69)\end{array}$ & $\begin{array}{l}0.9023 \\
0.0025\end{array}$ \\
\hline $1000-$ & $\begin{array}{l}0.0061^{*} \\
(1.95)\end{array}$ & $\begin{array}{r}-0.0627 \\
(-0.91)\end{array}$ & $\begin{array}{l}0.9196 \\
0.0018\end{array}$ \\
\hline $\begin{array}{l}\text { Non-manufacturing } \\
\text { Industries } \\
10-100\end{array}$ & $\begin{array}{l}0.0016^{* * * *} \\
(3.60)\end{array}$ & $\begin{array}{l}0.1640^{* * * *} \\
(3.27)\end{array}$ & $\begin{array}{l}0.8546 \\
0.0040\end{array}$ \\
\hline $100-1000$ & $\begin{array}{l}0.0147 * * * \\
(4.27)\end{array}$ & $\begin{array}{l}0.0416 \\
(1.33)\end{array}$ & $\begin{array}{l}0.8011 \\
0.0033\end{array}$ \\
\hline $1000-$ & $\begin{array}{l}0.0002 \\
(0.03)\end{array}$ & $\begin{array}{l}0.1635^{*} \\
(1.76)\end{array}$ & $\begin{array}{l}0.8364 \\
0.0024\end{array}$ \\
\hline
\end{tabular}

Notes: The values in parentheses are t-value.

$* * *$ significant at the $1 \%$ level $\quad * *$ significant at the $5 \%$ level

* significant at the $10 \%$ level

\{ EMBED Equation.3 \}: adjusted coefficient of determination

S.E.: standard error of the regression 
Table 15

Effects of Bank Failures in November in 1997 on Actual Growth Rate of Loans

\begin{tabular}{|c|c|c|}
\hline \multirow{2}{*}{$\begin{array}{c}\text { Firm size in terms } \\
\text { of capital } \\
\text { (million yen) }\end{array}$} & \multicolumn{2}{|c|}{$\begin{array}{l}\text { Deviation of loan growth rate from the recent trend } \\
\text { (\% per quarter) }\end{array}$} \\
\hline & $\begin{array}{c}\text { Fourth quarter } \\
\text { of } 1997\end{array}$ & $\begin{array}{l}\text { First quarter the } \\
\text { of } 1998\end{array}$ \\
\hline $\begin{array}{l}\text { Manufacturing } \\
\text { Industries } \\
10-100\end{array}$ & 0.57 & -1.02 \\
\hline $100-1000$ & -0.38 & -0.17 \\
\hline 1000- & 3.04 & 2.08 \\
\hline $\begin{array}{l}\text { Non-manufacturing } \\
\text { Industries } \\
10-100\end{array}$ & -1.18 & -2.06 \\
\hline $100-1000$ & 0.53 & -0.20 \\
\hline 1000- & 0.64 & -0.96 \\
\hline
\end{tabular}

Source: Quarterly Report of Financial Statements of Incorporated Business 
Table 16

Simulation Results: The Role of Bank Lending in the Recession of 1991-1993

(Billion yen at market prices in 1990)

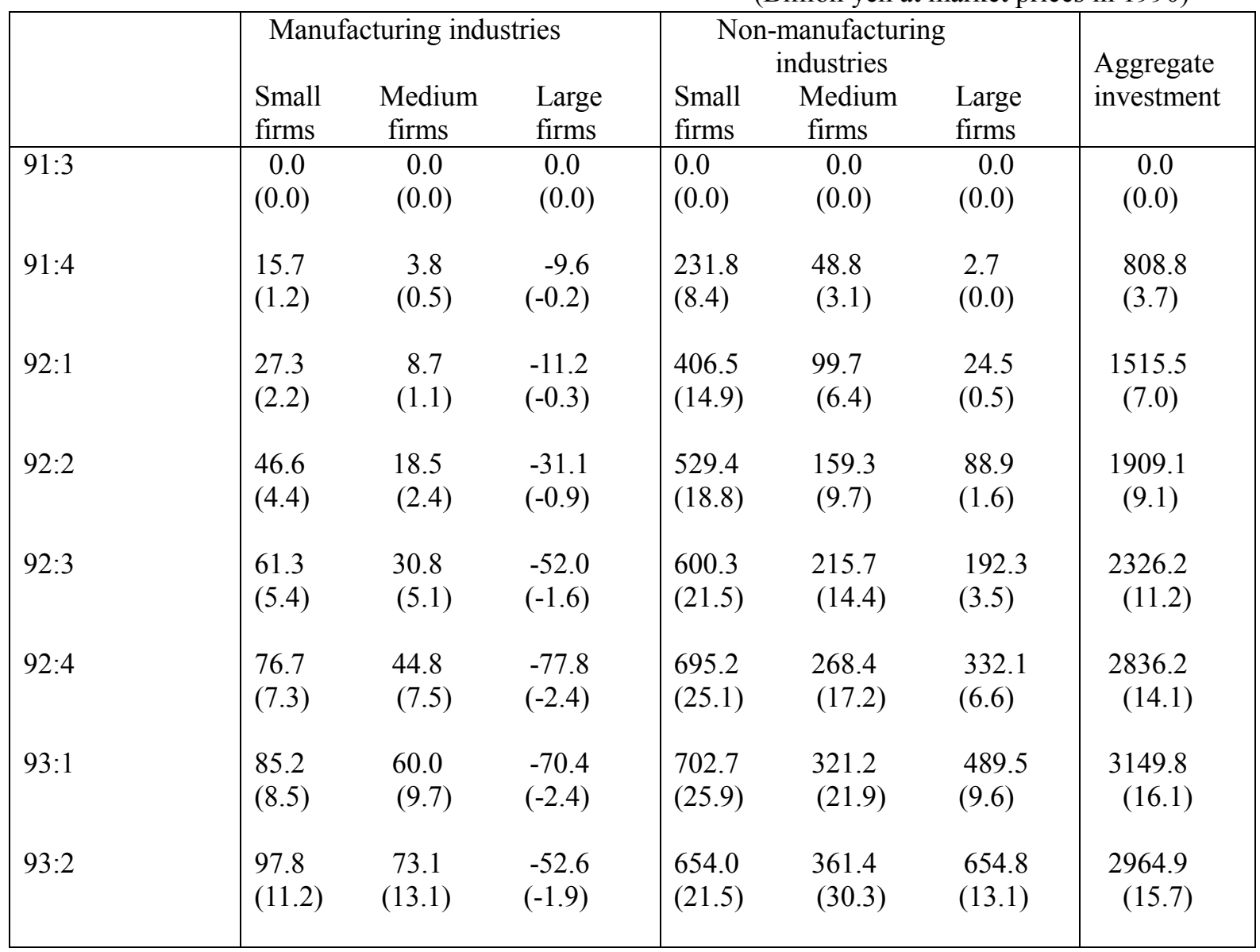

Notes: The values in parentheses are percentage change of fixed investment relative to actual figures. 
Table 17

Simulation Results: The Role of Real Factor in the Recession of 1991-1993

(Billion yen at market prices in 1990)

\begin{tabular}{|c|c|c|c|c|c|c|c|}
\hline & \multicolumn{3}{|c|}{ Manufacturing industries } & \multicolumn{3}{|c|}{$\begin{array}{l}\text { Non-manufacturing } \\
\text { industries }\end{array}$} & \multirow{2}{*}{$\begin{array}{l}\text { Aggregate } \\
\text { investment }\end{array}$} \\
\hline & $\begin{array}{l}\text { Small } \\
\text { firms }\end{array}$ & $\begin{array}{l}\text { Medium } \\
\text { firms }\end{array}$ & $\begin{array}{l}\text { Large } \\
\text { firms }\end{array}$ & $\begin{array}{l}\text { Small } \\
\text { firms }\end{array}$ & $\begin{array}{l}\text { Medium } \\
\text { firms }\end{array}$ & $\begin{array}{l}\text { Large } \\
\text { firms }\end{array}$ & \\
\hline $91: 3$ & $\begin{array}{l}31.8 \\
(2.1)\end{array}$ & $\begin{array}{l}17.1 \\
(2.0)\end{array}$ & $\begin{array}{l}19.6 \\
(0.5)\end{array}$ & $\begin{array}{l}44.5 \\
(1.6)\end{array}$ & $\begin{array}{c}-2.3 \\
(-0.2)\end{array}$ & $\begin{array}{r}6.5 \\
(0.1)\end{array}$ & $\begin{array}{l}221.1 \\
(1.0)\end{array}$ \\
\hline $91: 4$ & $\begin{array}{l}85.8 \\
(6.8)\end{array}$ & $\begin{array}{r}44.2 \\
(5.4)\end{array}$ & $\begin{array}{l}61.2 \\
(1.5)\end{array}$ & $\begin{array}{l}129.1 \\
(4.7)\end{array}$ & $\begin{array}{c}-0.2 \\
(-0.0)\end{array}$ & $\begin{array}{l}22.9 \\
(0.4)\end{array}$ & $\begin{array}{l}630.2 \\
(2.9)\end{array}$ \\
\hline $92: 1$ & $\begin{array}{l}153.6 \\
(12.2)\end{array}$ & $\begin{array}{r}65.9 \\
(8.4)\end{array}$ & $\begin{array}{l}119.1 \\
(3.3)\end{array}$ & $\begin{array}{l}215.7 \\
(7.9)\end{array}$ & $\begin{array}{l}12.6 \\
(0.8)\end{array}$ & $\begin{array}{l}50.5 \\
(1.0)\end{array}$ & $\begin{array}{c}1126.8 \\
(5.2)\end{array}$ \\
\hline $92: 2$ & $\begin{array}{l}232.0 \\
(22.1)\end{array}$ & $\begin{array}{c}86.9 \\
(11.3)\end{array}$ & $\begin{array}{l}203.0 \\
(5.7)\end{array}$ & $\begin{array}{l}336.9 \\
(12.0)\end{array}$ & $\begin{array}{l}39.6 \\
(2.4)\end{array}$ & $\begin{array}{l}85.7 \\
(1.6)\end{array}$ & $\begin{array}{c}1682.5 \\
(8.0)\end{array}$ \\
\hline $92: 3$ & $\begin{array}{l}328.6 \\
(28.8)\end{array}$ & $\begin{array}{r}115.2 \\
(19.1)\end{array}$ & $\begin{array}{l}308.0 \\
(9.5)\end{array}$ & $\begin{array}{l}492.6 \\
(17.7)\end{array}$ & $\begin{array}{r}78.5 \\
(5.2)\end{array}$ & $\begin{array}{l}131.5 \\
(2.4)\end{array}$ & $\begin{array}{r}2502.9 \\
(12.1)\end{array}$ \\
\hline $92: 4$ & $\begin{array}{l}445.3 \\
(42.4)\end{array}$ & $\begin{array}{c}154.8 \\
(25.8)\end{array}$ & $\begin{array}{l}411.8 \\
(12.9)\end{array}$ & $\begin{array}{l}679.8 \\
(24.6)\end{array}$ & $\begin{array}{l}130.9 \\
(8.4)\end{array}$ & $\begin{array}{l}189.1 \\
(3.8)\end{array}$ & $\begin{array}{r}3475.3 \\
(17.3)\end{array}$ \\
\hline $93: 1$ & $\begin{array}{l}567.9 \\
(56.4)\end{array}$ & $\begin{array}{r}196.9 \\
(31.7)\end{array}$ & $\begin{array}{r}534.4 \\
(18.5)\end{array}$ & $\begin{array}{l}900.2 \\
(33.2)\end{array}$ & $\begin{array}{l}188.4 \\
(12.9)\end{array}$ & $\begin{array}{l}257.7 \\
(5.1)\end{array}$ & $\begin{array}{r}4569.2 \\
(23.3)\end{array}$ \\
\hline $93: 2$ & $\begin{array}{l}682.1 \\
(78.2)\end{array}$ & $\begin{array}{c}222.1 \\
(39.8)\end{array}$ & $\begin{array}{l}673.3 \\
(24.4)\end{array}$ & $\begin{array}{l}1057.1 \\
(34.8)\end{array}$ & $\begin{array}{l}254.2 \\
(21.3)\end{array}$ & $\begin{array}{l}329.8 \\
(6.6)\end{array}$ & $\begin{array}{c}5120.1 \\
(27.1)\end{array}$ \\
\hline
\end{tabular}

Notes: The values in parentheses are percentage change of fixed investment relative to actual figures. 
Table 18

Simulation Results: The Effects of Credit Crunch in 1997-98

(Billion yen at market prices in 1990)

\begin{tabular}{|c|c|c|c|c|c|c|c|}
\hline & \multicolumn{3}{|c|}{ Manufacturing industries } & \multicolumn{3}{|c|}{$\begin{array}{l}\text { Non-manufacturing } \\
\text { industries }\end{array}$} & \multirow{2}{*}{$\begin{array}{l}\text { Aggregate } \\
\text { investment }\end{array}$} \\
\hline & $\begin{array}{l}\text { Small } \\
\text { firms }\end{array}$ & $\begin{array}{l}\text { Medium } \\
\text { firms }\end{array}$ & $\begin{array}{l}\text { Large } \\
\text { firms }\end{array}$ & $\begin{array}{l}\text { Small } \\
\text { firms }\end{array}$ & $\begin{array}{l}\text { Medium } \\
\text { firms }\end{array}$ & $\begin{array}{l}\text { Large } \\
\text { firms }\end{array}$ & \\
\hline $96: 2$ & $\begin{array}{c}0.0 \\
(0.0)\end{array}$ & $\begin{array}{c}0.0 \\
(0.0)\end{array}$ & $\begin{array}{l}0.0 \\
(0.0)\end{array}$ & $\begin{array}{l}0.0 \\
(0.0)\end{array}$ & $\begin{array}{c}0.0 \\
(0.0)\end{array}$ & $\begin{array}{r}0.0 \\
(0.0)\end{array}$ & $\begin{array}{c}0.0 \\
(0.0)\end{array}$ \\
\hline $96: 3$ & $\begin{array}{l}-4.1 \\
(-0.6)\end{array}$ & $\begin{array}{c}-0.1 \\
(-0.0)\end{array}$ & $\begin{array}{l}-7.6 \\
(-0.3)\end{array}$ & $\begin{array}{l}153.8 \\
(6.5)\end{array}$ & $\begin{array}{l}11.1 \\
(0.7)\end{array}$ & $\begin{array}{l}0.2 \\
(0.0)\end{array}$ & $\begin{array}{l}665.5 \\
(3.2)\end{array}$ \\
\hline $96: 4$ & $\begin{array}{c}2.3 \\
(0.3)\end{array}$ & $\begin{array}{c}-0.3 \\
(-0.1)\end{array}$ & $\begin{array}{l}-13.1 \\
(-0.5)\end{array}$ & $\begin{array}{l}264.7 \\
(11.7)\end{array}$ & $\begin{array}{l}15.4 \\
(1.0)\end{array}$ & $\begin{array}{r}1.3 \\
(0.0)\end{array}$ & $\begin{array}{c}1251.2 \\
(5.8)\end{array}$ \\
\hline $97: 1$ & $\begin{array}{c}6.3 \\
(0.8)\end{array}$ & $\begin{array}{l}-1.7 \\
(-0.2)\end{array}$ & $\begin{array}{l}-18.5 \\
(-0.6)\end{array}$ & $\begin{array}{l}252.2 \\
(9.0)\end{array}$ & $\begin{array}{r}23.7 \\
(1.5)\end{array}$ & $\begin{array}{r}4.3 \\
(0.1)\end{array}$ & $\begin{array}{l}992.3 \\
(4.4)\end{array}$ \\
\hline $97: 2$ & $\begin{array}{l}13.0 \\
(1.9)\end{array}$ & $\begin{array}{c}2.8 \\
(0.5)\end{array}$ & $\begin{array}{c}-16.4 \\
(-0.6)\end{array}$ & $\begin{array}{l}196.6 \\
(8.1)\end{array}$ & $\begin{array}{l}26.6 \\
(2.0)\end{array}$ & $\begin{array}{r}8.1 \\
(0.2)\end{array}$ & $\begin{array}{l}961.9 \\
(4.4)\end{array}$ \\
\hline $97: 3$ & $\begin{array}{l}18.6 \\
(2.4)\end{array}$ & $\begin{array}{c}5.2 \\
(0.8)\end{array}$ & $\begin{array}{c}-19.7 \\
(-0.7)\end{array}$ & $\begin{array}{l}209.5 \\
(10.1)\end{array}$ & $\begin{array}{l}26.0 \\
(1.8)\end{array}$ & $\begin{array}{r}6.6 \\
(0.1)\end{array}$ & $\begin{array}{c}1152.8 \\
(5.2)\end{array}$ \\
\hline $97: 4$ & $\begin{array}{l}23.4 \\
(3.4)\end{array}$ & $\begin{array}{l}12.0 \\
(1.9)\end{array}$ & $\begin{array}{c}-17.6 \\
(-0.6)\end{array}$ & $\begin{array}{l}297.2 \\
(14.5)\end{array}$ & $\begin{array}{r}29.5 \\
(1.8)\end{array}$ & $\begin{array}{r}5.1 \\
(0.1)\end{array}$ & $\begin{array}{c}1637.7 \\
(7.4)\end{array}$ \\
\hline $98: 1$ & $\begin{array}{l}19.1 \\
(2.9)\end{array}$ & $\begin{array}{l}18.5 \\
(3.0)\end{array}$ & $\begin{array}{c}-44.1 \\
(-1.3)\end{array}$ & $\begin{array}{l}344.2 \\
(19.8)\end{array}$ & $\begin{array}{r}15.7 \\
(1.1)\end{array}$ & $\begin{array}{l}-5.6 \\
(-0.1)\end{array}$ & $\begin{array}{c}1945.5 \\
(9.3)\end{array}$ \\
\hline
\end{tabular}

Notes: The values in parentheses are percentage change of fixed investment relative to actual figures. 
Figure 1 Growth Rate of Bank Loans

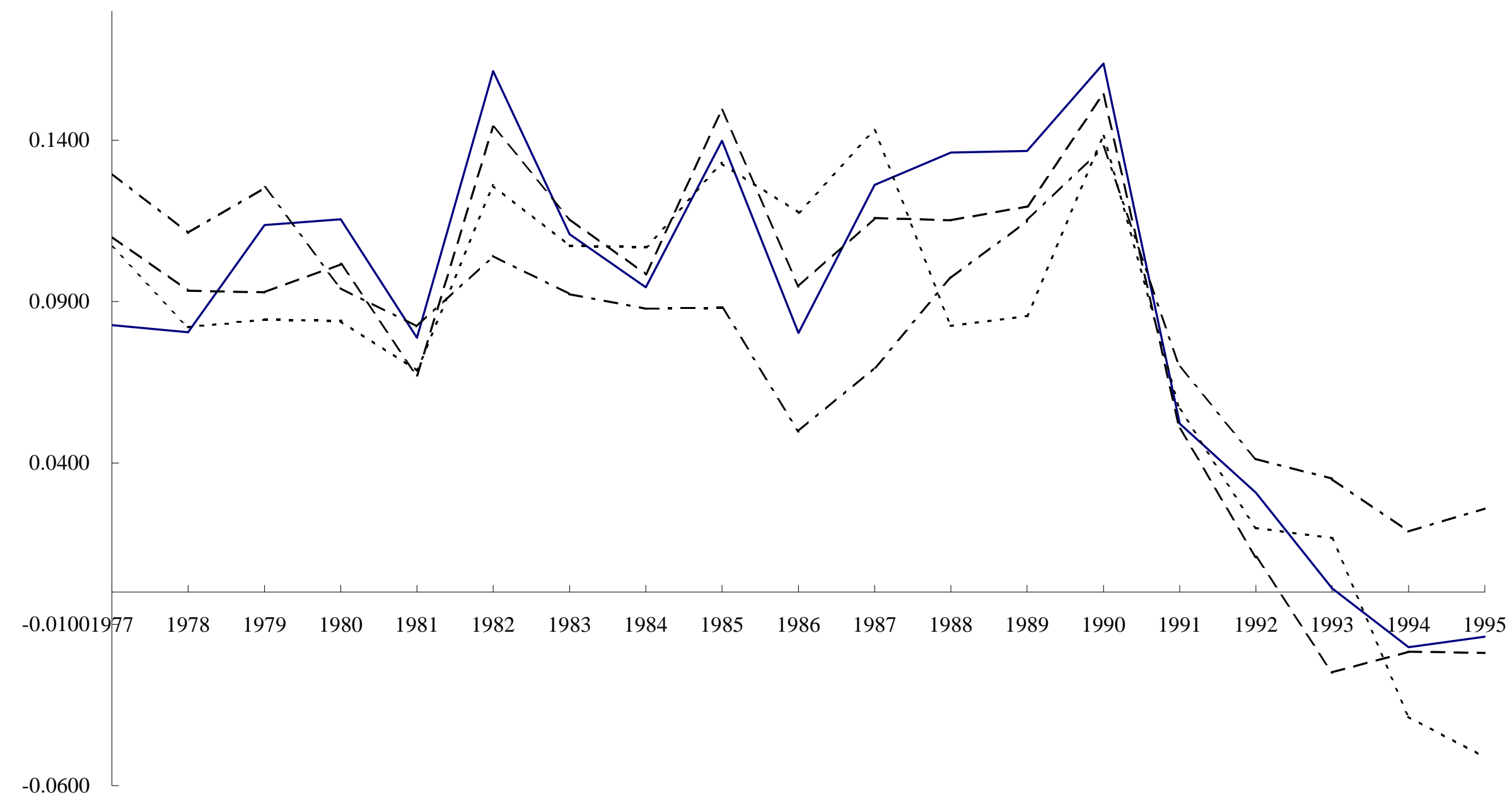

city banks --- long-term credit banks $\cdots \cdots$ trust banks $-\cdots-\cdot$ regional banks 
Figure 2 Proporion of Bank Loans to Small Firms

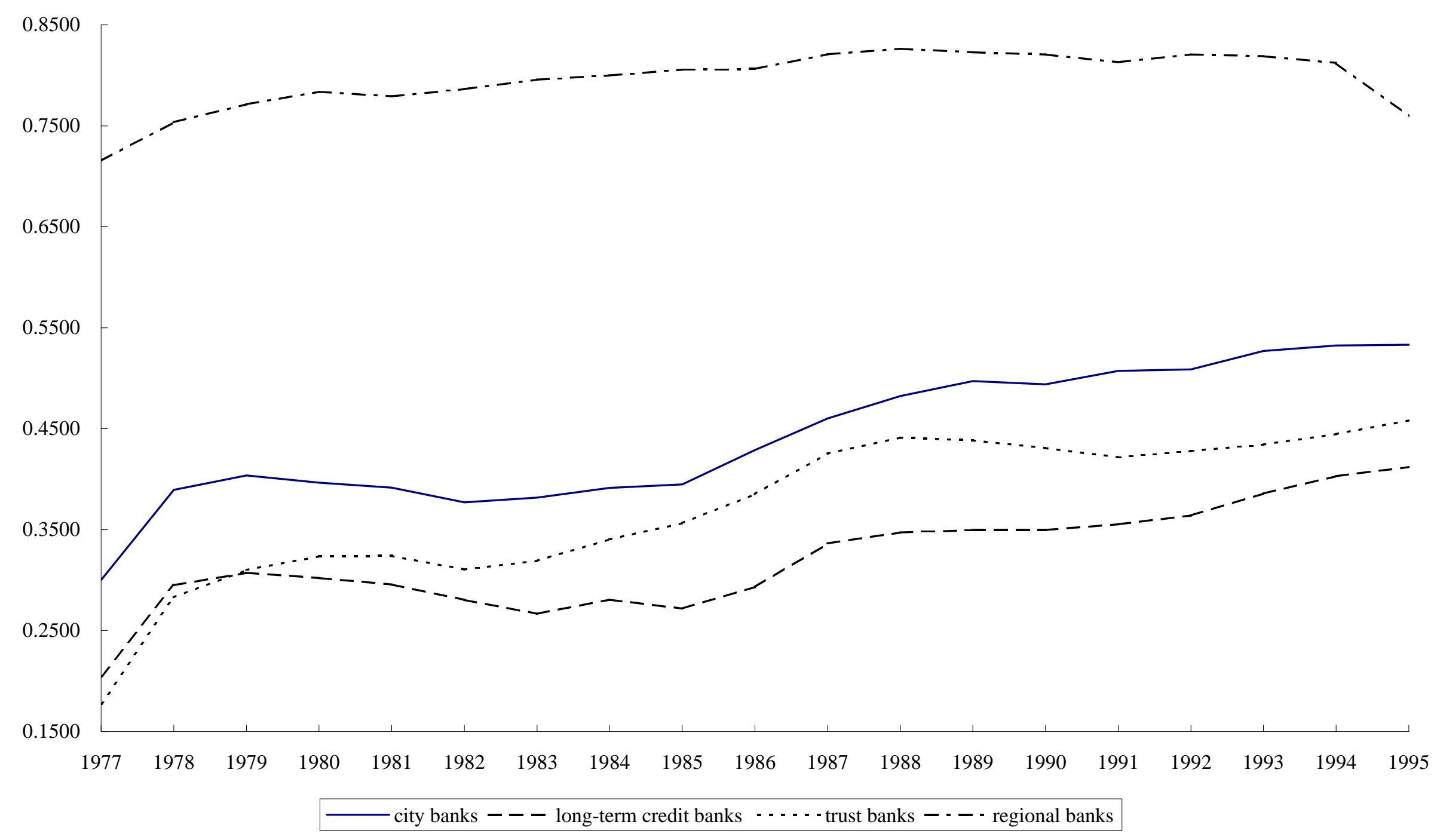

Source: Nikkei NEEDS Company Data Base 


\section{Figure 3 Proportion of Bank Loans secured by Real Estate}

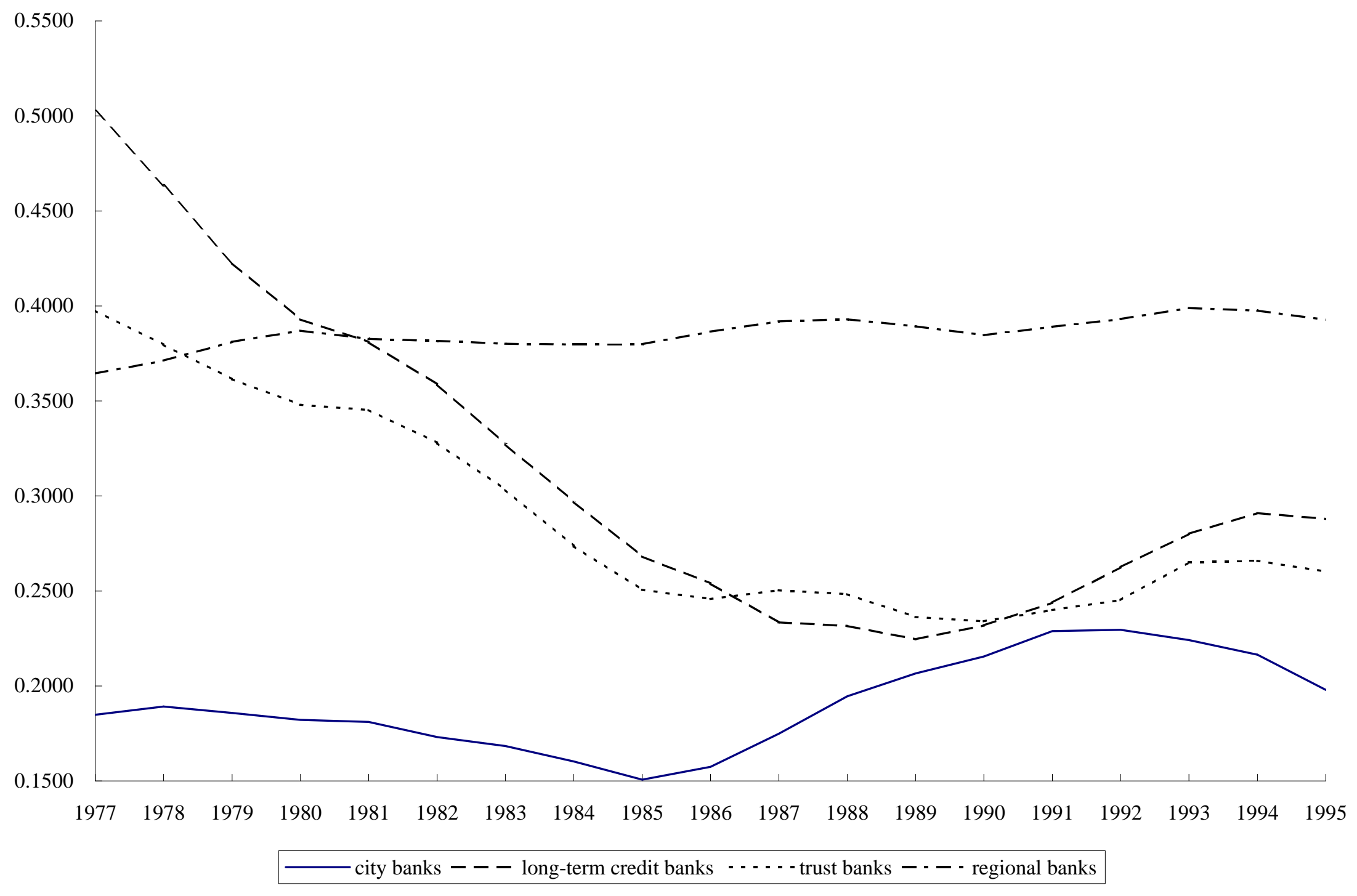


Figure 4 Proportion of Bank Loans to Non-manufacturing Industries

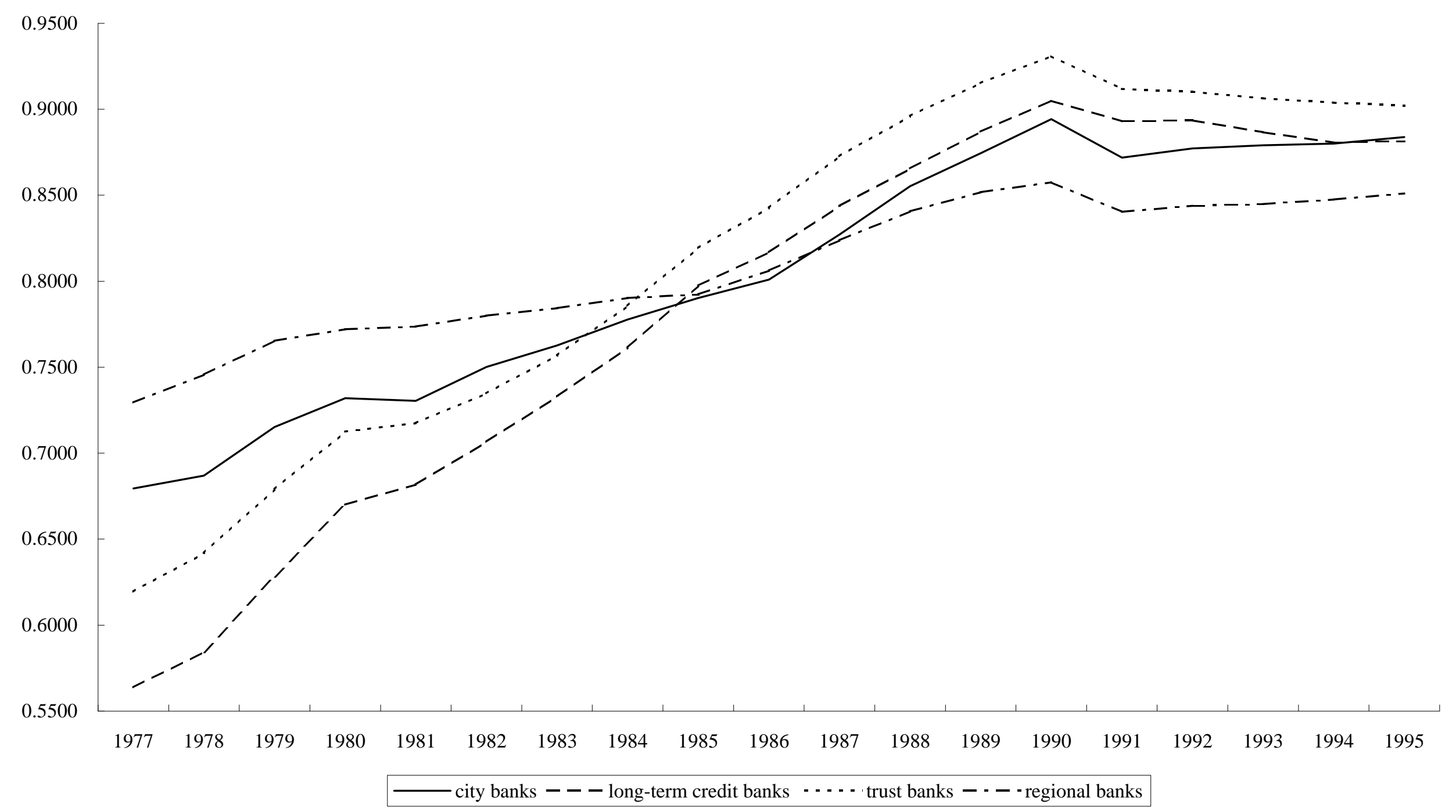

Source: Nikkei NEEDS Company Data Base 
Figure 5-1 Fixed Investment Rate by Firm Size:

Manufacturing Industries

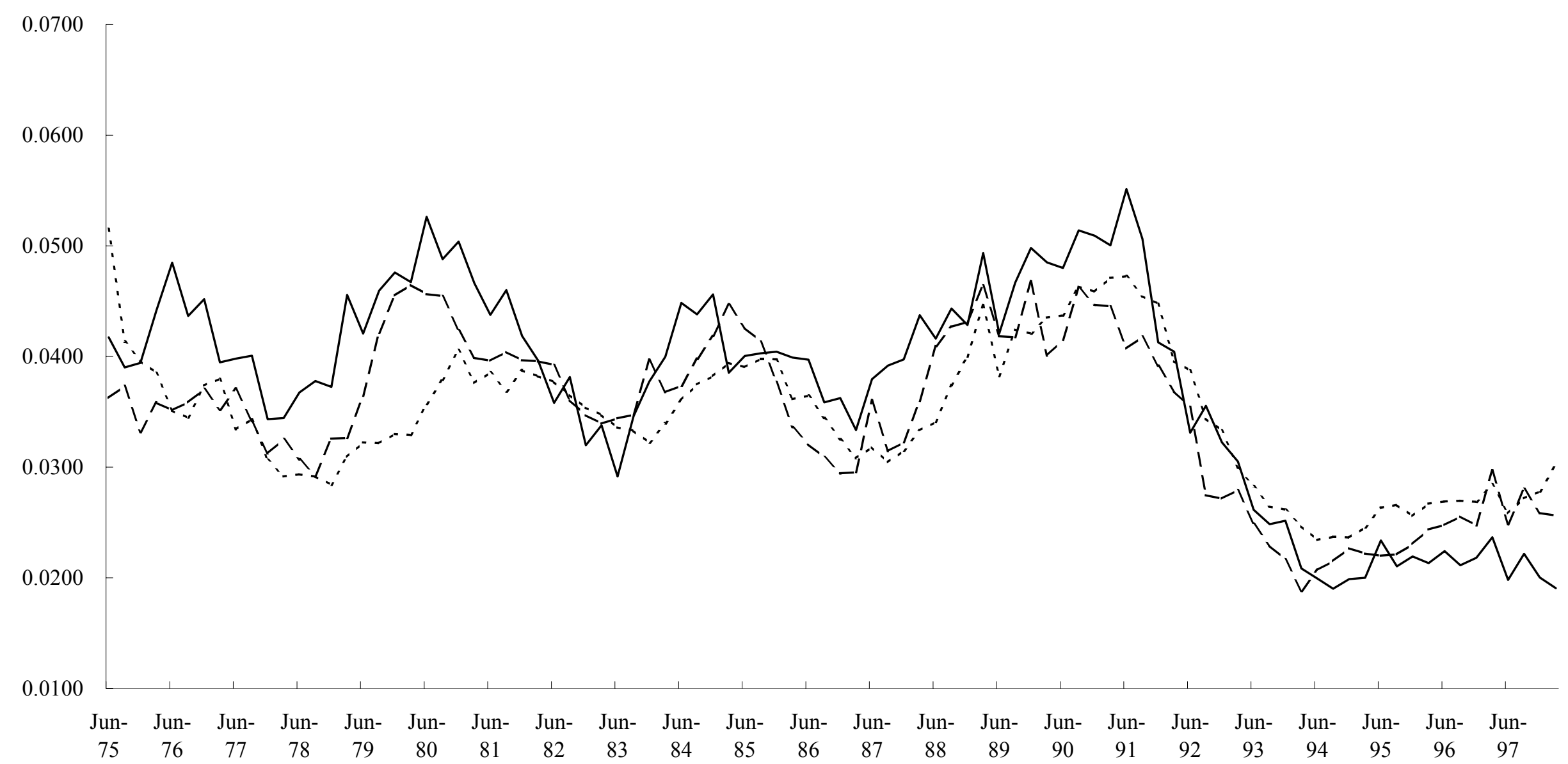

Fixed Investment Rate of Small Firms - - - Fixed Investment Rate of Medium Firms - - - - Fixed Investment Rate of Large Firms 
Figure 5-2 Fixed Investment Rate by Firm Size: Non-manufacturing Industries

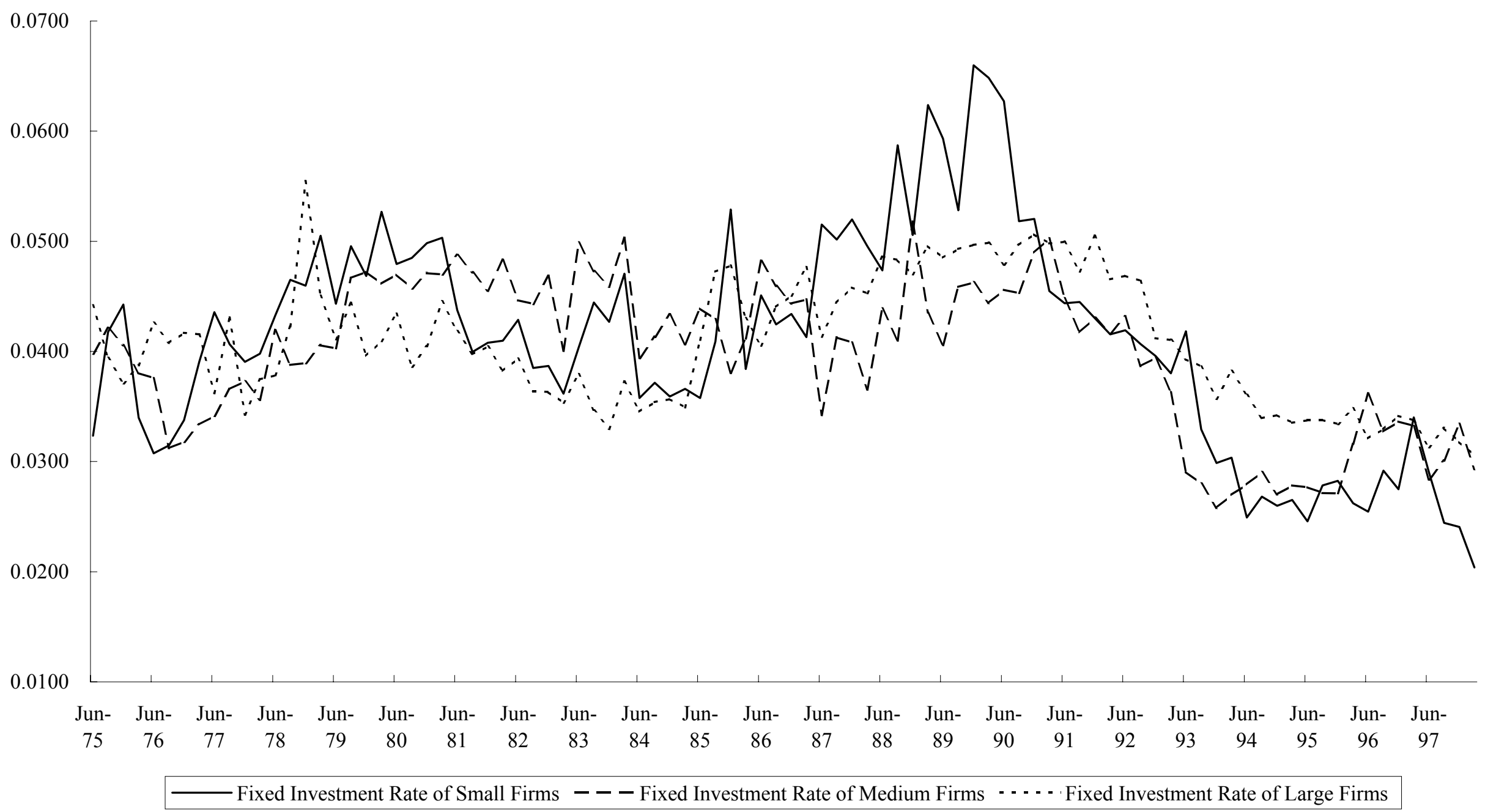


Figure 6

Balance Sheet of Banking Firm

\begin{tabular}{|c|c|}
\hline Assets & Liabilities \\
\hline Reserves & Deposits \\
Loans & Call money borrowing \\
Securities & Capital \\
\hline
\end{tabular}


Figure 7 Growth Rate of Deposit

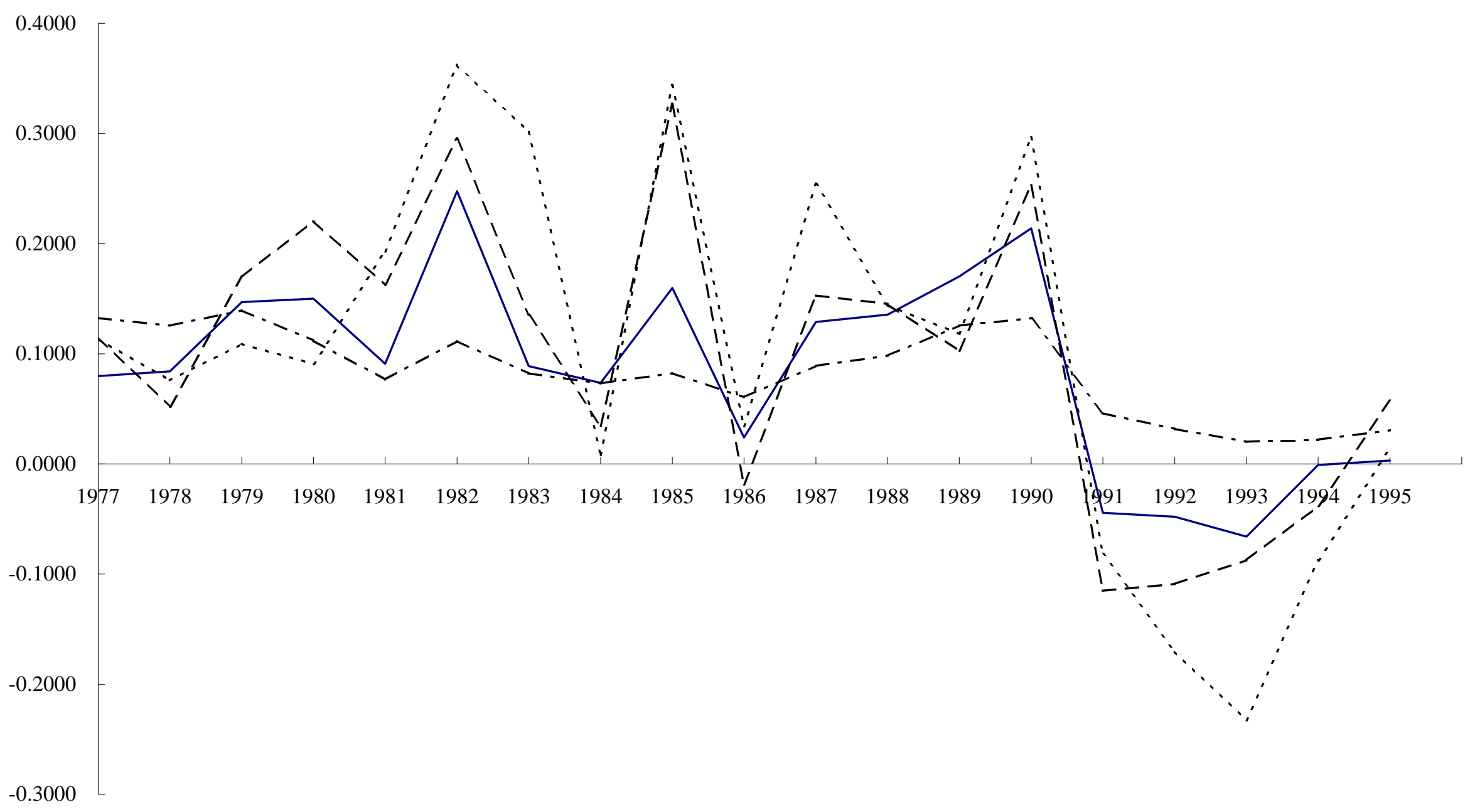

city banks --- long-term credit banks $\cdots-$ - trust banks $-\cdots-$ regional banks 
Figure 8-1 Marginal q by Firm Size:

Manufacturing Industries

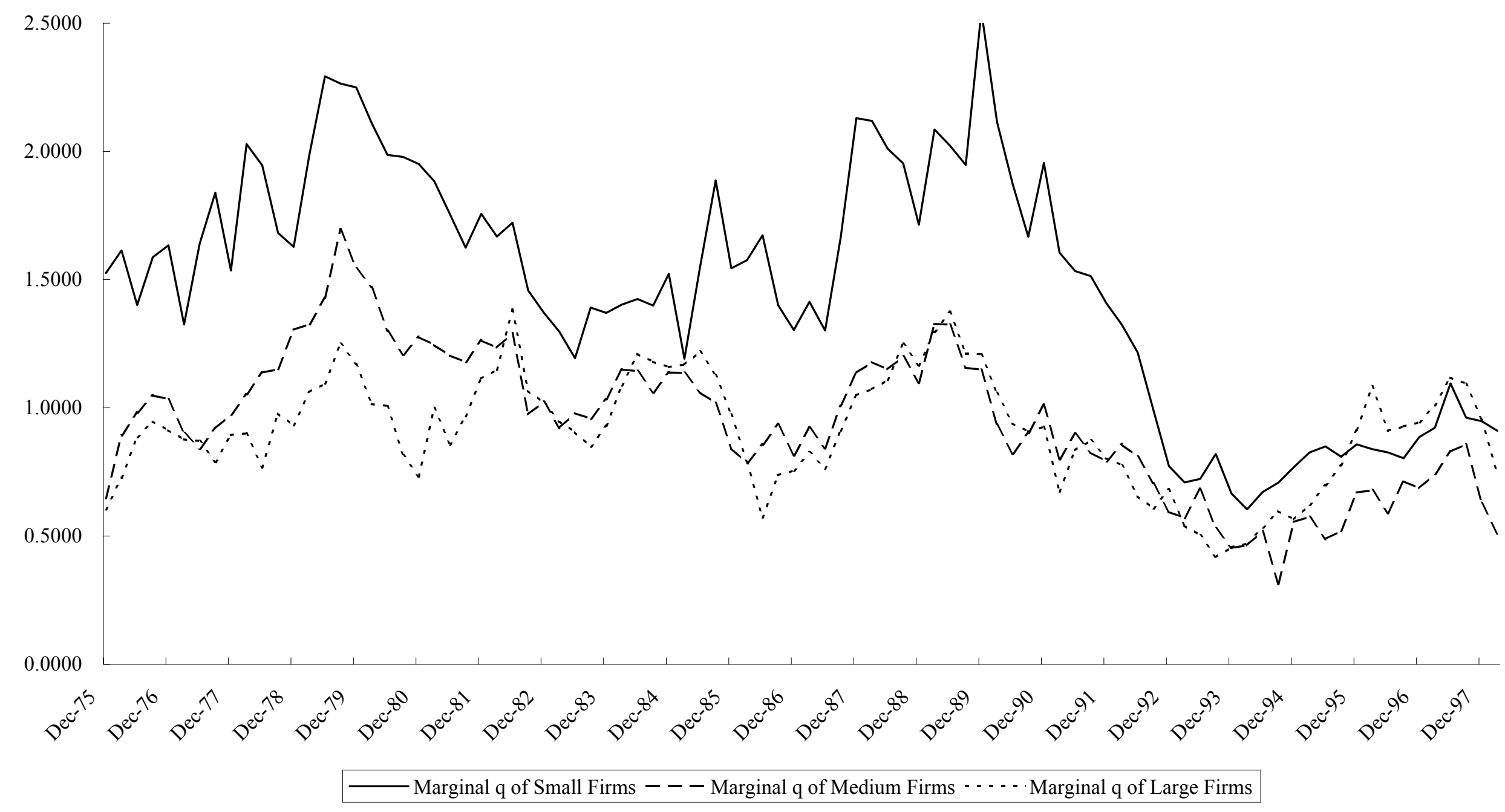


Figure 8-2 Marginal q by Firm Size:

Non-manufacturing Industries
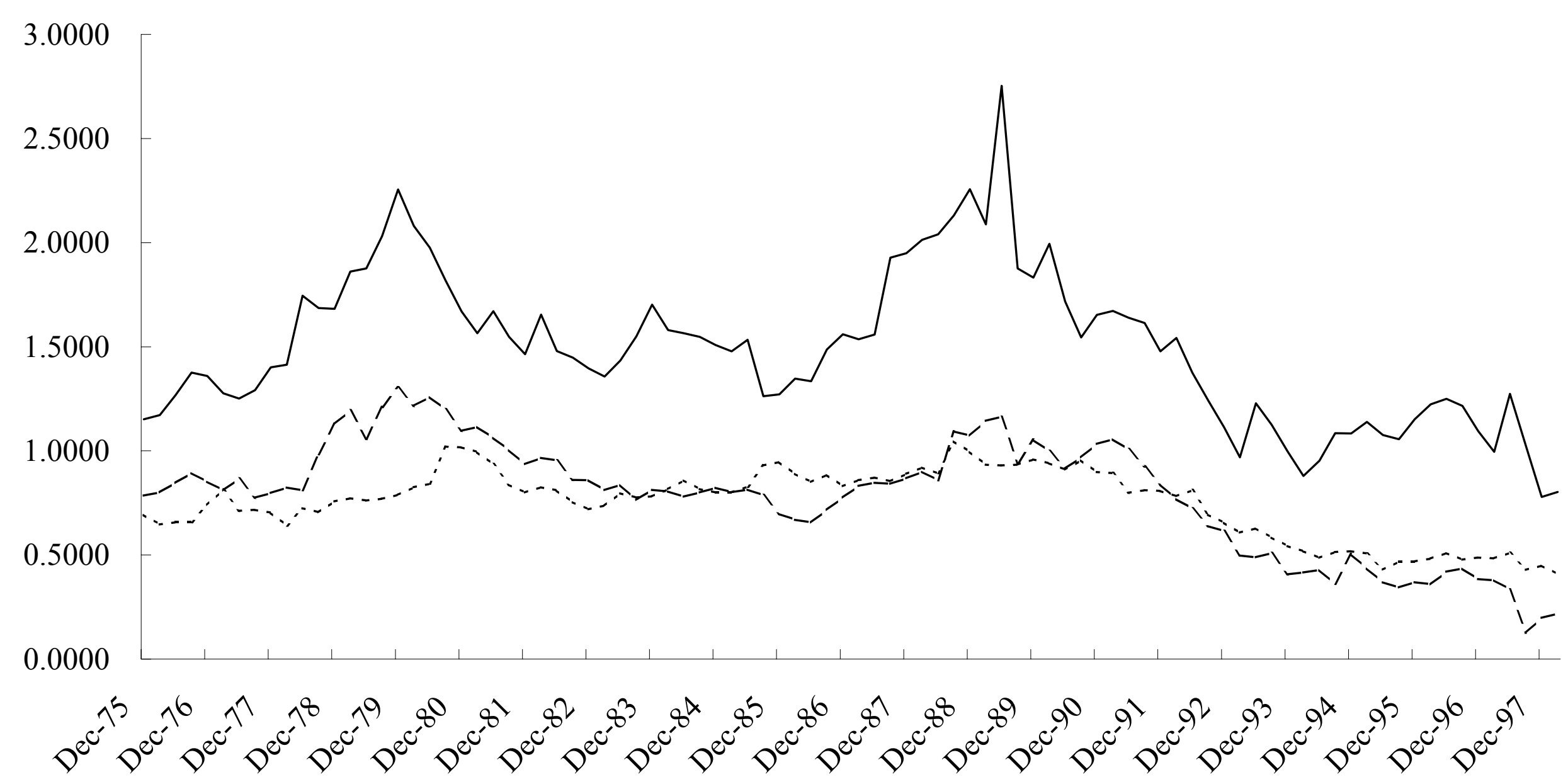

Marginal q of Small Firms - - - Marginal q of Medium Firms $\cdots \cdots$... Marginal q of Large Firms 
Figure 9-1 Effects of Restrictions of Bank Loans to Real Estate Industry: Manufacturing Industries

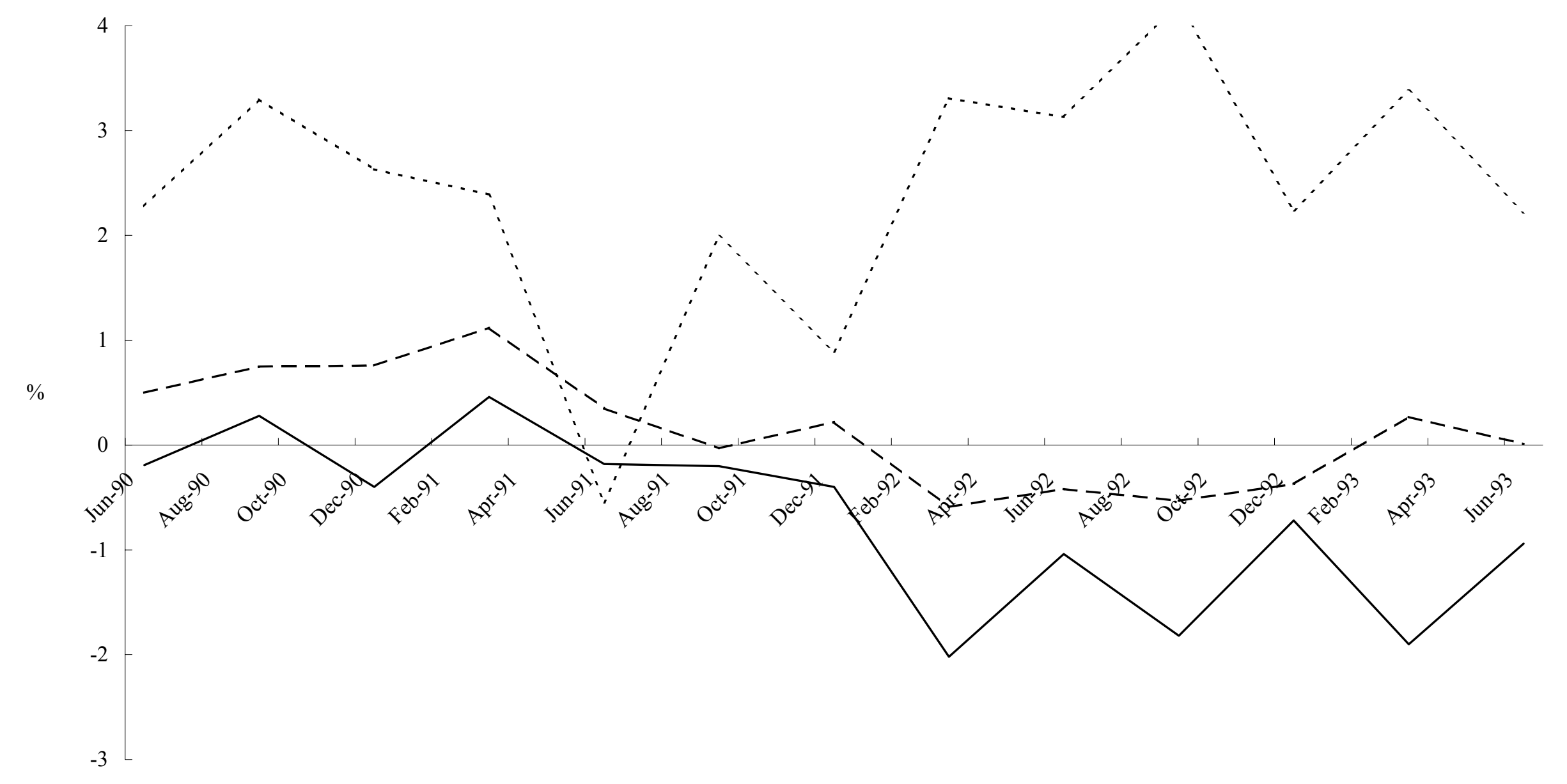

Small firm group - - - Medium firm group - . . - Large firm group 
Figure 9-2 Effects of Restrictions of Bank Loans to Real Estate Industry: Non-manufacturing Industries

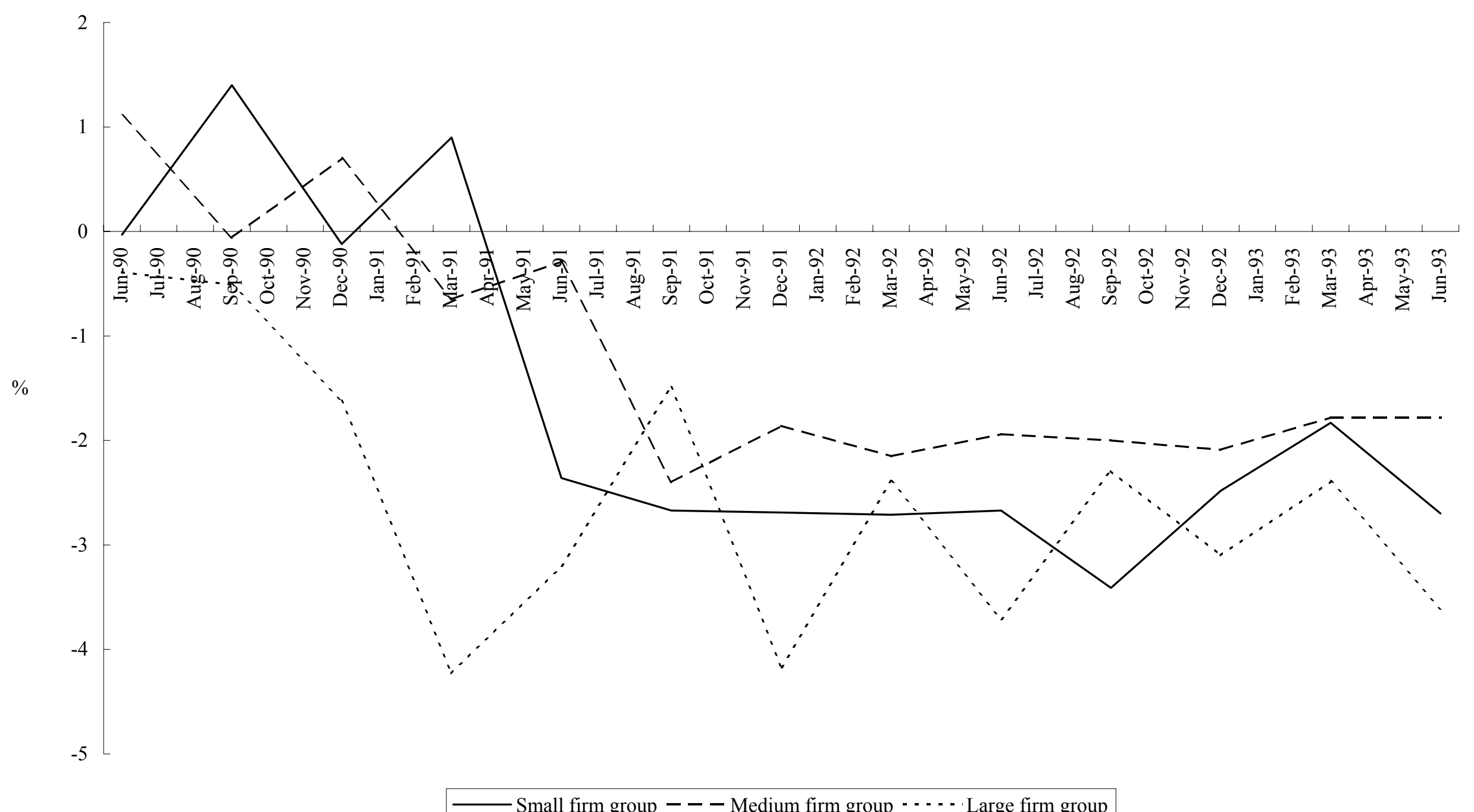

